\title{
PRE-OPERATIONAL \\ ENVIRONMENTAL MONITORING PLAN \\ FOR THE \\ DEVICE ASSEMBLY FACILITY \\ AT THE \\ NEVADA TEST SITE
}

BY

FRED D. FERATE

JANUARY 1995

WORKED PERFORMED UNDER

CONTRACT NO. DE-AC08-94NV11432

PREPARED BY:

REYNOLDS ELECTRICAL \& ENGINEERING CO., INC.

POST OFFICE BOX 98521

LAS VEGAS, NV 89193-8521 


\section{DISCLAIMER}

This report was prepared as an account of work sponsored by an agency of the United States Government. Neither the United States Govermment nor any agency thereof, nor any of their employees, makes any warranty, express or implied, or assumes any legal liability or responsibility for the accuracy, completeness, or usefulness of any information, apparatus, product, or process disclosed, or represents that its use would not infringe privately owned rights. Reference herein to any specific commercial product, process, or service by trade name, trademark, manufacturer, or otherwise, does not necessarily constitute or imply its endorsement, recommendation, or favoring by the United States Govemment or any agency thereof. The views and opinions of authors expressed herein do not necessarily state or reflect those of the United States Government or any agency thereof.

This report has been reproduced directly from the best available copy.

Available to DOE and DOE contractors from the:

Office of Scientific and Technical Information

P.O. Box 62

Oak Ridge, Tennessee 37831

Prices available from (615) 576-8401

Available to public from the:

National Technical Information Service

U.S. Department of Commerce

5285 Port Royal Rd.

Springfield, VA 22161 


\section{DISCLAIMER}

Portions of this document may be illegible in electronic image products. Images are produced from the best available original document. 


\title{
PRE-OPERATIONAL ENVIRONMENTAL MONITORING PLAN \\ FOR THE \\ DEVICE ASSEMBLY FACILITY \\ AT THE \\ NEVADA TEST SITE
}

\author{
EDITED BY \\ YVONNE TOWNSEND
}

JANUARY 1995

WORKED PERFORMED UNDER

CONTRACT NO. DE-AC08-94NV11432

\section{PREPARED FOR THE}

U. S. DEPARTMENT OF ENERGY

NEVADA OPERATIONS OFFICE

\section{PREPARED BY:}

REYNOLDS ELECTRICAL \& ENGINEERING CO., INC.

POST OFFICE BOX 98521

LAS VEGAS, NV 89193-8521 


\section{TABLE OF CONTENTS}

Page

1.0 INTRODUCTION $\ldots \ldots \ldots \ldots \ldots \ldots \ldots \ldots \ldots \ldots \ldots \ldots \ldots \ldots \ldots \ldots \ldots$

2.0 BACKGROUND DATA .................... 2

2.1 ENVIRONMENTAL SURVEILLANCE . . . . . . . . . . 2

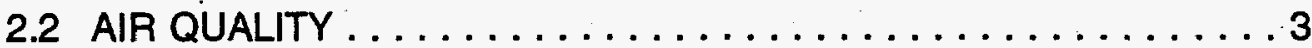

2.3 FLORA AND FAUNA MONITORING . . . . . . . . . . 4

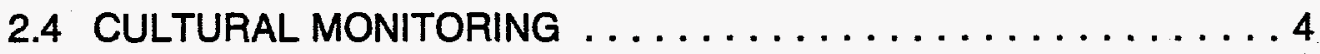

3.0 SCOPE OF MONITORING PLAN $\ldots \ldots \ldots \ldots \ldots \ldots \ldots$

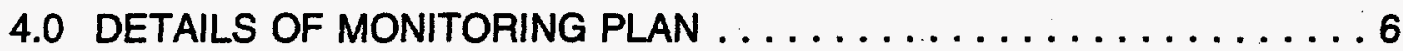

4.1 DESIGN CRITERIA $\ldots \ldots \ldots \ldots \ldots \ldots \ldots \ldots \ldots \ldots \ldots \ldots \ldots$

4.2 MONITORING DESIGN $\ldots \ldots \ldots \ldots \ldots \ldots \ldots$

4.3. PERMIT REQUIREMENTS ... . . . . . . . . . . . . . . 10

4.4 QUALITY ASSURANCE .................. 10

4.5 DATA QUALITY OBJECTIVES ... . . . . . . . . 11

4.6 DISCUSSION OF ESTIMATED COSTS . . . . . . . . . . . . 11

5.0 PRESENT STATUS OF PRE-OPERATIONAL MONITORING . . . . . . 12

6.0 RECORD KEEPING AND REPORTS $\ldots \ldots \ldots \ldots \ldots \ldots$

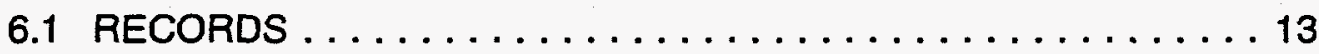

6.2 REPORTS .......................... 14

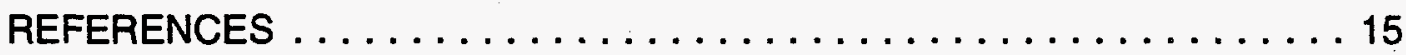

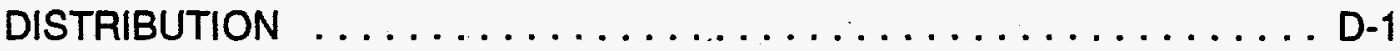




\section{LIST OF ATTACHMENTS}

Page

ATTACHMENT A.1: TABLE 5 FROM REFERENCE 4: ESTIMATED INVENTORIES OF MAJOR MANMADE RADIONUCLIDES IN NTS SURFACE SOIL AS OF JANUARY $1,1990 \ldots \ldots \ldots \ldots \ldots \ldots \ldots$

ATTACHMENT A.2: ADAPTATION OF FIGURE 3 REFERENCE 11: NORTHERN BOUNDARY OF THE RANGE OF THE DESERT TORTOISE ON THE NEVADA TEST SITE

ATTACHMENT A.3: ADAPTATION OF FIGURE 8 FROM REFERENCE 12: TORTOISES FOUND DURING POPULATION AND IMPACT MONITORING STUDIES ON THE NEVADA TEST SITE AND YUCCA MOUNTAIN DURING 1987-1990 . . . . . . . . . A.3-1

ATTACHMENT A.4: $\quad$ WIND ROSE FOR DAF . . . . . . . . . . . . .

ATTACHMENT A.5: $\quad$ WIND ROSE FOR SAND SPRING RANGE $\ldots \ldots \ldots \ldots \ldots$ A.5-1

ATTACHMENT A.6: SUMMARY OF RESULTS OF 1993 PRE-OPERATIONAL ECOLOGICAL MONITORING AROUND THE DAF

ATTACHMENT A.7: PERMITTING REQUIREMENTS $\ldots \ldots \ldots \ldots \ldots \ldots \ldots$ A.7-1

ATTACHMENT A.8: DATA QUALITY OBJECTIVES $\ldots \ldots \ldots \ldots \ldots \ldots \ldots$ A.8-1

ATTACHMENT A.9: $\quad$ ESTIMATED COSTS $\ldots \ldots \ldots \ldots \ldots \ldots \ldots \ldots \ldots$ A.9.1

ATTACHMENT A.10: MAP SHOWING AIR SAMPLER AND TRITIATED WATER VAPOR SAMPLER LOCATIONS

ATTACHMENT A.11: MAP SHOWING SOIL AND VEGETATION SAMPLING LOCATIONS 


\subsection{INTRODUCTION}

\section{Overview}

Nuclear explosives operations have been and may continue to be an important component of the DOE mission at the NTS. This mission has been to conduct the nation's nuclear testing program in a safe, secure, and efficient manner while assuring full compliance with state and federal regulations, and DOE orders and directives. These operations have generally included assembly, disassembly or modification, staging, transportation, and testing of nuclear explosive devices. They-may also include maintenance, repair, retrofit, and surveillance. The Device Assembly Facility (DAF) was constructed to provide a dedicated facility in which to prepare nuclear explosives assemblies for their intended disposition. This facility will provide for combined operations (replacing two separate facilities) and incorporates state-of-the-art safety and security features while minimizing the risks of environmental impacts.

The facility has been completed but not yet operated, so the impacts to be considered will be based on normal operations and not on the impacts of construction activities. The impacts will arise from nuclear explosives operations that require the handling of high explosives in combination with special nuclear materials.

Wastes from operation of the earlier device assembly facilities have included grams of epoxies, pints of solvents, and small quantities of waste explosives. These are hazardous (includes radioactive) wastes and are disposed of in accordance with state and federal regulations. Assuming similar operations at the DAF, non-hazardous (includes nonradioactive) solid waste would be transported to a permitted landfill. Waste explosives would be sent to the Area 11 Explosive Ordnance Disposal Unit. Other hazardous waste would be sent to the Area 5 Radioactive Waste Management Site for shipment or burial.

\section{Affected Environment}

The DAF is situated on the western margin of Frenchman Flat. The average temperature ranges from -3 degrees Celsius in January to 36 degrees Celsius in July. It is in an arid climate with annual precipitation of less than $18 \mathrm{~cm}(7 \mathrm{in})$.

Hydrology The DAF is within the Ash Meadows subbasin of the Death Valley groundwater basin. The depth to groundwater is $360 \mathrm{~m}(1180 \mathrm{ft})$. Neither perennial streams nor wetlands exist in the vicinity of the DAF.

Flora and Fauna None of the plant species in the vicinity of the DAF are listed as threatened or endangered. Due to the desert landscape of the DAF area, the animal species are small, nocturnal or migratory. The desert tortoise, a threatened species, is the only animal species on the U. S. Fish and Wildlife Service Threatened and Endangered Species List that is common to the NTS. Because of this, consultations were held with the U. S. Fish and Wildife Service and a Biological Opinion ${ }^{1,2}$ was issued. All subsequent construction was in accordance with this Opinion. Also, DAF operations will be conducted inside a cleared and fenced area in accordance with the Biological Opinion. 


\section{Environmental Consequences of DAF Operation}

Air Quality Air pollutants are expected to be generated by engine exhausts and dust from vehicular traffic. Two emergency generators are available to provide backup electrical power; emissions from emergency operation of these units would be negligible.

The possibility of an accidental nuclear or high explosives detonation is extremely remote because of administrative controls, personnel training and certification, psychological evaluations, and safety features designed into the building. The design features, special filtration facilities, and negative pressures in the bays would minimize the release of contaminants. Air exhausted from the DAF will pass through High Efficiency Particulate Air (HEPA) filters.

Liquid Discharges No liquids containing hazardous materials will be discharged during operations at the DAF. The great depth to groundwater and the slow vertical movement of any liquids spilled will prevent contamination of groundwater. Sewage and other nonhazardous water effluent from the facility is contained in a sewage lagoon system and a state permit authorizes treatment via an evaporation/percolation basin.

There are five double-wall fiberglass tanks underground for storage/holding: one for non-PCB transformer oil spill containment, one for fuel spill containment, two for diesel fuel, and one for decontamination/fire suppression liquids. When planned retrofitting of these tanks has been completed, they will comply with the more restrictive regulations being contemplated by EPA. More information on this subject is available from the Subject Matter Expert in REECo's Environmental Management Division.

A stormwater conveyance and diversion structure has been constructed to protect the facility and supporting structures from runoff during rainstorm events.

Design Basis Accident In the event of the most serious postulated nuclear explosive operational (non-criticality) accident, it is estimated that the maximum collocated worker exposure from plutonium due to the accident would be $530 \mathrm{mrem} / \mathrm{yr}$, and the maximum public exposure would be $25 \mathrm{mrem} / \mathrm{yr}^{3}$

\subsection{BACKGROUND DATA}

\subsection{ENVIRONMENTAL SURVEILLANCE}

\section{Radionuclides in Soil}

Table 5 from Reference 4, included as Attachment A.1, suggests a small inventory of Am, Pu, $\mathrm{Co}, \mathrm{Cs}$ and $\mathrm{Sr}$ in Area 6 soil. The concentrations are relatively low; only 3 or 4 NTS areas have lower concentrations. The figure in this report suggests that only the northeastem portion of Area 6 was surveyed, and not the immediate area around the DAF. 


\section{Air Surveillance}

Environmental surveillance data for $1993^{5}$ indicate that gross beta concentrations in Area 6 are typical for the NTS. The concentrations of ${ }^{239+240} \mathrm{Pu}$ in air were higher than that for Area 6 in eight other areas of the NTS and lower in seven other areas, with an average in Area 6 of $23 \mathrm{aCi} / \mathrm{m}^{3}$. Routine sampling was not conducted in Area 6 for tritium and noble gases as there are no known sources of these radionuclides in Area 6.

\section{Radionuclides in Water}

There are three wells that supply water for Area 6 facilities; they will also be used to supply water to the DAF. These are Wells 4, C, and C-1. The average tritium concentration in these in 1993 was $11 \mathrm{pCi} / \mathrm{L}$ (far below the Safe Drinking Water Act limit of $20,000 \mathrm{pCi} / \mathrm{L}$ ). This is mainly due to Wells $\mathrm{C}$ and $\mathrm{C}-1$, which historically have had detectable tritium (detectable, using a very sensitive enrichment method) in their water samples. There has been no detectable plutonium in the water system. The average gross alpha concentration in these wells in 1993 was $9.1 \mathrm{pCi} / \mathrm{L}$. Because the gross alpha concentration was above $5 \mathrm{pCi} / \mathrm{L}$, the Safe Drinking Water Act regulations required that in this case radium analyses also be performed, and that the measured concentration of ${ }^{226} \mathrm{Ra}$ be less than $3 \mathrm{pCi} / \mathrm{L}$; this was done, and the annual average measured concentration of ${ }^{226} \mathrm{Ra}$ for these wells was $0.8 \mathrm{pCi} / \mathrm{L}$. The average ${ }^{90} \mathrm{Sr}$ concentration was also low, at $0.1 \mathrm{pCi} / \mathrm{L}$. Further details are available in Reference 5.

\subsection{AIR QUALITY}

An air monitoring study ${ }^{6}$ performed at the NTS in 1990 found the air quality at the NTS to be uniformly within the current federal and state primary and secondary standards. In addition, simultaneous tests of selected point sources of air emissions were found to be in compliance with applicable permits. It was concluded, as a result of the study, that NTS air quality is well within all applicable local, state and federal regulations.

Air Quality Operating Permit AP 9711-0555 was issued by the state of Nevada on April 27, 1995, and is valid until December 4, 1999. It covers all of Area 23 (Mercury) and surface disturbances over all of the NTS, including the area where the DAF is located. This permit allows DOE/NV to engage in construction or other activity resulting in minimum variable surface area disturbances including "surface preparation for underground nuclear test shots and all other surface disturbances at the Test Site," so long as the conditions and requirements of the permit are adhered to. DAF operations, as is the case with operation of other facilities on the NTS, must comply with state regulations for fugitive dust emissions.

As mentioned earlier, two emergency generators are available at the DAF to provide backup electrical power. No permit is presently needed to operate these generators; however, the state has indicated to DOE/NV that once their Operating Permit Program is approved by the EPA, they will notify DOE/NV of the need and deadline for applying to the state for a Class I Operating Permit. Depending on their instructions, the emergency generators at the DAF may be among the sources which must be included in the application. 


\title{
2.3 FLORA AND FAUNA MONITORING
}

\author{
Federally Listed Endangered, Threatened, and Candidate Species
}

During the preconstruction survey conducted for the DAF in 1984 by EG\&G Energy Measurements, ${ }^{3,7}$ no threatened or endangered plant species were found. No evidence of threatened, endangered, or candidate plant species has been found during subsequent flora and fauna monitoring, performed in conjunction with this pre-operational monitoring plan. ${ }^{8,9}$

The desert tortoise (Gopherus agassizii), a threatened species, is the only animal species on the U.S. Fish and Wildlife Service's Threatened and Endangered Species List found on the NTS. ${ }^{10}$ Attachments A.2 and A.3, based on Figure 3 from a 1994 EG\&G Report, "The Northern Boundary of the Desert Tortoise Range on the Nevada Test Site" ${ }^{11}$ and Figure 8 from a 1991 EG\&G Report, "The Distribution and Abundance of Desert Tortoises on the Nevada Test Site", ${ }^{12}$ respectively, confirm that the DAF is within the range of tortoise habitat on the NTS. In particular, Attachment A.3 suggests that the DAF may be near an area of high tortoise population.

References 10 and 12 were among documents used by the U. S. Fish and Wildlife Service as the basis for developing the Biological Opinion. This Opinion finds that "specific DOE/NV activities at NTS planned for fiscal years 1992 through 1995 are not likely to jeopardize the continued existence of the threatened Mojave population of the desert tortoise."

Pursuant to the requirements of the Endangered Species Act of 1973, the Opinion estimates the anticipated incidental take of desert tortoise individuals and habitat that could occur as a result of the DOE/NV activities identified in the Biological Assessment. It further defines reasonable and prudent measures which DOE/NV should take to minimize the take, and to implement those measures sets terms and conditions with which DOE/NV must comply in order to be exempt from the prohibitions of the Act. Additional requirements include various reporting and notification procedures which must be followed and, if the incidental take limit is reached, immediate cessation of all activities which may take tortoises, until consultation with the Service is re-initiated and a new agreement is reached.

\section{State Sensitive Species}

No state of Nevada sensitive plant or animal species are known to be present in the area around the DAF.

\subsection{CULTURAL MONITORING}

\section{Archaeological Sites}

In 1984 a cultural resource reconnaissance of the area in which the DAF was to be constructed was carried out. ${ }^{13}$ In the corresponding report it was indicated that no significant cultural resources were discovered in the area. The state of Nevada Division of Historic Preservation and Archaeology later issued a memorandum concurring that: "The construction of a nuclear device assembly area in the surveyed area of Frenchmen Flat will have no effect on properties of Register quality." ${ }^{3}$ 


\subsection{SCOPE OF MONITORING PLAN}

\section{Scope}

This pre-operational monitoring plan is intended to prescribe a series of radiological and ecological measurements and observations in the vicinity of the existing DAF complex which will provide baseline environmental data against which any pertinent future effects of DAF operations on the environment may be compared.

\section{Observations}

The types of DAF operations considered when drawing up this plan are those for which the DAF was designed (or similar ones), i.e., nuclear test device assembly and disassembly. These will involve the storage, transportation, and assembly or disassembly of high explosives in combination with special nuclear material.

The basic premise and purpose of this pre-operational (and any future operational) monitoring plan is to ensure as much as possible that data are collected which will allow detection and quantification of any measurable effects (i.e., measurable dispersion of radionuclides or ecological changes) on the environment due to normal operation of the DAF. Various accident scenarios have been discussed in the DAF Safety Analysis Report, ${ }^{14}$ and some of these, particularly the scenarios involving possible dispersion of tritium oxide, plutonium, or fission products, could result in detectable changes from baseline values. Nevertheless, this pre-operational environmental monitoring plan is designed to establish baseline information to allow the detection and quantification of any future, and generally more subtle, effects due to normal, routine DAF operations.

An important limitation on the scope of this plan is that it does not include monitoring for baseline concentrations of chemical compounds.

DOE Order 5400.1, "General Environmental Protection Program,"15 requires that an environmental study "be conducted prior to start up of a new site, facility, or process which has the potential for significant adverse environmental impact." The study should "characterize existing physical, chemical, and biological conditions that could be affected; establish background levels of radioactive and chemical components; characterize pertinent environmental and ecologic parameters; and identify potential pathways for human exposure or environmental impact as a basis for determining the nature and extent of the subsequent routine operational and emergency effluent monitoring and environmental surveillance programs."

By chemical conditions or components are meant non-naturally occurring chemicals hazardous to the health of human beings and other life forms, and specifically, chemicals listed in the Resource Conservation and Recovery Act (RCRA). The geographical location of the DAF was essentially desert before construction, although it was subject to fallout from local and worldwide atmospheric nuclear tests. There was no modern human occupation, and only transient activities were carried out in the area, such as the use of a few dirt roads, setting up power lines, and the like.

There may have been an occasional localized spill associated with some of these activities; if so, the existence or locations of such spills are unknown at this time. Generally, by process knowledge the area around the DAF is considered free of RCRA compounds. It is assumed that any RCRA compound found in the future in the vicinity of the DAF will be considered a 
spill, cleaned up, and responsibility assigned at that time either to the DAF or to some other activity, according to the corresponding assessment of cause. Accordingly it is felt that pre-operational measurements for RCRA specified hazardous chemicals are not useful or appropriate.

\subsection{DETAILS OF MONITORING PLAN}

\subsection{DESIGN CRITERIA}

The basic criterion has been to establish the pre-operational status of the environs of the Device Assembly Facility (DAF) with respect to the distributions of flora and fauna, and existing concentrations of radionuclides.

As noted previously, construction had essentially been completed when this plan was requested and pre-operational measurements were begun. The buildings and much of the infrastructure and surrounding roads and graded areas had already replaced the original desert environment. Thus when pre-operational measurements were initiated, there had already taken place significant changes in flora and fauna distribution as compared with the pristine desert environment; however, the effects of construction on preexisting radionuclides outside of the immediate construction area are likely to have been negligible. Therefore, pre-operational measurements have been and are being made to establish baseline conditions from this stage of construction, for comparison with conditions after the DAF becomes operational.

The media to be studied will be air, soil, sewage water, and plants and animals resident around the DAF. There are no streams, ponds, or springs in the area, except for the sewage pond. The existing program for sampling water from the three wells which supply the water system to be used for the DAF is deemed to give adequate information on the groundwater system.

\subsection{MONITORING DESIGN}

\section{Air Sampling}

A wind rose based on data collected at the DAF from February 1993 through July 1994 (see Attachment A.4) indicates that prevailing winds are primarily from the north and northnorthwest directions, and from the south-southwest and southwest. This is corroborated by the wind rose for the Sand Spring Range, about 2 1/2 miles south of the DAF, from June 1988 through December 1991 (see Attachment A.5). Thus the indicated locations for air samplers, to sample air coming from the DAF, are in the north-northeast to northeast sector, and the south to south-southeast sector, on circles centered at the DAF.

Air Particulate and Halogen Gas Samplers An air sampler designed to collect radioactive particulates and radioiodines will be set up in each of the two indicated sectors, to operate continuously for at least one year, with weekly sample collection. The minimum number of samples to be collected at each station is 47.

Gamma spectroscopy will be performed separately on each particulate and charcoal filter; each particulate filter will also be measured for gross beta activity. Monthly composites of the particulate filters will be analyzed for ${ }^{238} \mathrm{Pu}$ and ${ }^{239+240} \mathrm{Pu}$ using plutonium alpha spectroscopy. 
Noble Gas Samplers No noble gas samplers will be deployed. There is no known source of radioactive noble gas (i.e., xenon or krypton) nearby. The nearest noble gas samplers have been located for several years at Gate 200 in Area 5, at the E-MAD (Engine Maintenance Assembly and Disassembly) facility in Area 25, and at BJY and the Gravel Pit in Area 1, and these have yielded essentially background concentrations of ${ }^{85} \mathrm{Kr}$. It will be assumed that levels at the DAF are equal to these background levels, which in 1993 averaged $27 \mathrm{pCi} / \mathrm{m}^{3} .5$

Tritiated Water Vapor Samplers An air sampler designed to collect water vapor for subsequent tritium analysis will be set up in each of the two indicated sectors, to operate continuously for at least one year, with biweekly sample collection. Each sample will be analyzed to determine the concentration of tritiated water vapor at the sampling location. The minimum number of samples to be collected at each station is 23 .

\section{Water Sampling}

Supply Well Sampling The DAF will be supplied by the Area 6 water supply system, which receives water from Wells 4, C, and C-1. All of these wells are regularly sampled on a quarterly basis as part of the routine Environmental Monitoring Program. No additional monitoring is required specifically for the DAF.

Endpoint Sampling No endpoint water sampling will be performed at the DAF for the purpose of determining baseline values. Water samples are regularly collected from one or two taps connected to each of the five water systems on the NTS, as part of the routine Environmental Monitoring Program. Samples are already collected regularly from two different endpoints on the Area 6 water system.

Sewage Pond Sampling Samples will be collected from the DAF sewage pond on a quarterly basis for at least a year, following standard Environmental Section sample collection procedures. Quarterly samples will be analyzed for tritium, gross beta, and isotope specific gamma and plutonium activity concentrations; one sample will be analyzed annually for ${ }^{90} \mathrm{Sr}$. The minimum number of samples to be collected is four. This is the same sampling and analysis protocol used for other sewage lagoons on the NTS.

\section{Soil Sampling}

It is important to know what concentrations of radionuclides presently exist in the soil, so that any future variations from these baseline values can be identified. As indicated above, valuable information on radionuclide concentrations in NTS Area 6 soil has been gathered and published previously. ${ }^{4}$ The soil sampling described below will complement those data by focusing on the sector of Area 6 in the immediate vicinity of the DAF.

The materials and processes for which the DAF is designed to be used involve special nuclear material, which contains alpha emitters, and tritium. In addition, if a low yield nuclear detonation were to occur, there could be dispersion of fission products, most of which are gamma emitters.

Soil samples will be collected in at least twelve directions around the DAF, and approximately 300 to $400 \mathrm{~m}$ from the DAF entrance door. The locations and directions will be chosen so that they lie roughly on a circle with the DAF at its center, and so that all directions are more or less equally represented. Two aliquots of soil moisture from each of six of these locations, distributed uniformly around the DAF, will be analyzed for tritium. 
The distribution of insoluble radionuclides in the soil is naturally inhomogeneous. The cost of preparing and analyzing a sufficient number of duplicates to obtain a reasonable estimate of precision at a particular location is prohibitive. For this reason, and because the types of soil and the fallout histories of soils in the vicinity of the DAF are similar, one aliquot at each of twelve locations will be analyzed by gamma spectroscopy, and by alpha spectroscopy for uranium, americium, and plutonium. This will allow a global estimate of precision for the totality of samples taken. Analyses on additional aliquots will be considered if the standard deviation of the results for a given isotope exceeds 100 percent in any case where the average activity concentration is greater than 10 times the average minimum detectable concentration.

The minimum number of soil samples to be collected is twelve. The minimum number of soil moisture samples to be collected is six, where two aliquots of each sample are to be separately analyzed for tritium content. The soil moisture samples will be collected near the collection locations for the vegetation samples, as described in the following paragraph.

\section{Vegetation Sampling}

Duplicate vegetation samples (leaves) will be collected from dominant plant species (Joshua trees [Yucca brevifolia], and creosotebush [Larrea tridentata]) in undisturbed terrain in various directions around the DAF, and 300 to $400 \mathrm{~m}$ from the entrance door. This will be done for at least six equally spaced directions. These plants will be marked, so that leaves from the same plants can be sampled in future years during operational monitoring. The minimum number of samples to be collected for each plant type is twelve.

Gamma spectroscopy, and a measurement of the tritium content of plant moisture, will be performed for each vegetation sample.

\section{Flora and Fauna Monitoring}

Baseline data on plants and animals near the DAF were collected during the 1993 sampling season. A detailed description of methods, results, and recommendations for future monitoring have been published in Reference 8 . A summary of the results is included as Attachment A.6.

Sampling efforts focused on ephemeral and perennial plants, birds, mammals, and reptiles. Methods were designed to determine patterns of distributions and abundances of various species prior to operation of the DAF, i.e., to determine what patterns exist in the area.

Two types of patterns were investigated, those due to natural variations in the habitat, and those associated with non-nuclear DAF operations, such as construction, or the use of roads and the physical plant. Separation of these factors was somewhat problematic, since most construction around the DAF had taken place before monitoring began. In particular, the selection of "undisturbed" control sites was sometimes difficult, since there may have existed subtle differences in plant or animal populations due to the presence of the DAF which were not obvious, and are possibly unknowable.

Following are some details on methods used. Full descriptions of the methods, results, and discussion may be found in Reference 8.

Ephemeral Plants Ephemeral plants in the desert environment of the NTS appear briefly in the spring and then die out. Thus time available for sampling is limited to several weeks in 
late April and early May of most years. In this short time period an attempt was made to determine which species were present, their densities and total production (biomass), relative dominance, and evidence for changing dominance.

Data were gathered to compare several techniques for estimating density, and measurements were also made in disturbed and nondisturbed areas to evaluate the effects of a graveled area, a paved road, and a dirt road on ephemerals.

Perennial Plants Perennial plants were measured on five sets of 20 plots arranged in concentric bands around the DAF. The closest set was located between the outer security fence surrounding the DAF buildings and $300 \mathrm{~m}$ from the front door of the DAF. Other sets were located between 300 and $400 \mathrm{~m}, 400$ and $500 \mathrm{~m}, 500$ and $600 \mathrm{~m}$, and 1000 and $1500 \mathrm{~m}$ from the front door. In each of the 20 directions, and in each band, a survey plot five meters long and two wide was selected, and all perennial plants within the plot were censused. The Joshua tree, creosotebush, and Nevada Mormon tea plant nearest the southem end of most plots was measured and marked. Also, frequency and types of disturbances around the DAF were recorded, by selecting the disturbance nearest the south end of each plot.

Birds Bird use at the DAF sewage pond was recorded from March to November, and compared to undisturbed habitats nearby. Visits per hour for various species were recorded and compared. Special attention was given to ravens, a known predator of young desert tortoises.

Breeding bird density was estimated for selected species at the DAF using a variable circular plot technique. Eight such plots were chosen in undisturbed habitat, five located away and three near the sewage pond. A bird species list was developed.

Small Mammals The objective of the small mammals portion of the pre-operational monitoring at the DAF was to obtain baseline data on species diversity and relative abundance. Simple site characterization of small mammal populations was deemed a priority. The effect of the roadsides was also investigated.

Three traplines of $1180 \mathrm{~m}$ each were set up, one along the paved road from the DAF to Mercury Highway, one from the east side of the sewage ponds to the southeast, and one approximately $300 \mathrm{~m}$ north of the flood dike. Areas close to the DAF were not trapped, as the degree of disturbance severely inhibited small mammal activities such as foraging and burrowing. Two types of traps were used. Species, animal number, sex, age, reproductive status, location, trap type, weight and any notes were recorded on data sheets and the animals were then released.

One attempt was made to capture bats along one edge of the DAF sewage lagoon, with poor results, attributed in part to relatively high winds.

Reptiles Reptiles near the DAF include lizards, snakes, and desert tortoises. Lizards are widespread and common in deserts, including around the DAF, and are primarily diumal, easily seen, and relatively easy to study. For these reasons they are the most useful reptile group for studying the effects of human activities.

DAF reptile studies dealt with four topics: effect of the main DAF access road; differences between disturbed areas around the DAF buildings and other local nondisturbed areas; effect of the diversion ditch around the DAF; and investigations of reptiles species of special concern. Several sampling techniques were used and analyzed. Results from and 
comparisons of these sampling techniques are discussed, and a reptile species list compiled.

\subsection{PERMIT REQUIREMENTS}

The principal permits required for the construction and operation of the DAF, and the regulations which require them, are listed in Attachment A.7.

\subsection{QUALITY ASSURANCE}

A Quality Assurance/Quality Control (QAQC) program exists for all monitoring and analysis conducted by the Reynolds Electrical \& Engineering Co., Inc. (REECo) Analytical Services Department (ASD). Standard Operating Procedures that describe QA/QC in detail are listed here.

ASD Quality Procedure Numbers

AAHzz.B.01.00

AAHzz.B.02.00

AAHzz.B.03.00

AAHzz.B.06.00

AAHzz.B.07.00

AAHzz.B.08.01

AAHzz.B.08.02

AAHzz.B.12.01

AAHzz.B.12.02

AAHzz.B.12.03

AAHzz.B.12.04

AAHzz.B.12.05

AAHzz.B.12.06

AAHzz.B.12.07

AAHzz.B.12.08

AAHzz.B. 13.00

AAHzz.B.04.00

AAHzz.B.14.00
ASD Quality

Procedure Name

ASD Quality Implementing Procedure

ASD Organization

Personnel Training and Qualification

Control of Documents and Records

Verification of Computer Software

Quality Control Samples and Control Charts

Data Discrepancies and Corrective Actions

Sample Traceability

Standards Traceability

Operational Check Requirements

Calibration Requirements

Reagents Verification

ASD Analytical Logbooks

Verification of Pipettes

Standards Preparation for Radioanalysis

Assessment of Data Usability

Management Assessment

Independent Assessment

These programs focus on the following practices, with only slight differences between types of sampling and analyses.

- Personnel training and work assignment qualifications.

- Sample acquisition documentation.

- Sample chain-of-custody control.

- Procedural compliance.

- Yield determination of radiochemistry procedures.

- Analytical QA including blanks, spikes, and blind replicates being used as QC samples to verify the maintenance of procedural control. 
- Routine source and background count checks entered on control charts to document counting system performance.

- Use of standards traceable to the National Institute of Standards and Technology (NIST) and NIST reference materials for instrument calibration and QC samples.

- Calibration of sampling, analytical, and counting instruments.

- Preventive and corrective maintenance for all systems which are crucial to data quality.

- Review of QC data and QC charts to assure control of methods and processes.

- Review of analytical data before reporting.

- External audits and surveillances..Intemal compliance surveillances.

- Actively participating in the interlaboratory QA programs conducted by the DOE, the EPA, and others.

\subsection{DATA QUALITY OBJECTIVES}

Data Quality Objectives (DQOs) have been set for each of the media being sampled for both radiological and non-radiological analyses. Each of the DQOs addresses the following parameters:

- Representativeness

- Comparability

- Completeness

- Precision

- Accuracy

- Detectability

The necessary DQOs are shown in Attachment A.8.

\subsection{DISCUSSION OF ESTIMATED COSTS}

An overview of the distribution of costs for the various activities involved in the preparation and implementation of this Plan is presented in Attachment A.9. Approximately $\$ 371 \mathrm{~K}$ will have been spent over a three year period for preparation of the plan $(\$ 39 \mathrm{~K})$, radiological monitoring $(\$ 131.2 \mathrm{~K})$, analysis and reporting of the radiological results $(\$ 7.8 \mathrm{~K})$, biological monitoring $(\$ 111.8 \mathrm{~K})$, analysis and reporting of the biological results $(\$ 81.5 \mathrm{~K})$.

The major cost for radiological baseline monitoring, as is the case for routine radiological environmental surveillance, is that of the radioanalyses required, with actual sampling, and preparation of reports, running far behind. Costs for biological monitoring are more evenly divided between the field work and preparation of the reports. Biological monitoring is very labor intensive, requiring many hours in the field to obtain adequate data. Similarly, each area 
of biological monitoring requires a different area of expertise; several persons are involved, each analyzing data and preparing the portion of the report covering their specialty.

\subsection{PRESENT STATUS OF PRE-OPERATIONAL MONITORING}

As indicated above, pre-operational ecological monitoring was performed around the DAF in 1993 to obtain baseline flora and fauna data. Methods, results and analyses are described in Reference 8. A summary of the 1993 results is included with this plan as Attachment A.6. Additional pre-operational ecological monitoring, more modest in scope, was performed in 1994; the methods and results of this monitoring will be presented in Reference 9, in preparation.

During the period since October of 1993 radiological pre-operational monitoring of the DAF has been undertaken in several phases. Following is a summary description of the nature of those efforts. Measured values, and a formal analysis of the data, will be published when all radiological pre-operational monitoring data are available.

\section{Air Sampling}

Air Particulate and Halogen Gas Samplers Continuous low volume air samplers to collect radioactive particulates and radioiodines were set up in October 1993 in two locations near the DAF. One location is at a power substation northeast of the DAF; the other is at a point south-southeast of the DAF, where the sampler was run off an electrical generator, since no line power was available. The locations are indicated on the map enclosed as Attachment A.10.

Filters were exchanged weekly from October 1993 through December 1994. A gross beta measurement was made on each particulate filter. Gamma spectroscopy was performed separately on each particulate and charcoal filter through September 1994. From October 1994 through December 1994, gamma spectroscopy was performed only on the particulate filters, the charcoal filters being available for measurement in case the gross beta count on a particulate filter were to give a statistically improbable higher than nomal value. Monthly composites of the particulate filters were analyzed for ${ }^{238} \mathrm{Pu}$ and ${ }^{239+240} \mathrm{Pu}$ using plutonium alpha spectroscopy.

Tritiated Water Vapor Samplers A tritiated water vapor sampler was collocated with each of the air samplers described above, from October 1993 through December 1994. Air was continuously pumped through a column containing hygroscopic crystals. of silica gel. Columns were exchanged every two weeks. Water was distilled from the silica gel and measured for tritium activity; tritiated water vapor concentrations were then calculated from these values and the measured air flow.

\section{Water Sampling}

Sewage Pond Sampling Quarterly collections from the DAF sewage ponds were initiated the fourth quarter of 1994, and will continue for three more quarters. DAF sewage pond sample collection and analysis will then be made part of the routine NTS environmental surveillance sewage pond network. Quarterly samples will be analyzed for tritium, gross beta, and isotope 
specific gamma and plutonium activity concentrations; one sample will be analyzed annually for ${ }^{90} \mathrm{Sr}$.

\section{Soil Sampling}

Soil samples have been collected along a rough circle, approximately 300 to $400 \mathrm{~m}$ from the DAF entrance door. Gamma spectroscopy, and alpha spectroscopy for uranium, americium, and plutonium are being performed on samples for 12 locations distributed approximately uniformly around the DAF. These locations are indicated on the map enclosed as Attachment A.11.

Methods are being tested for collecting water from the soil to determine tritium content in the soil moisture. The locations chosen for sampling are also indicated in Attachment A.11.

\section{Vegetation Sampling}

Duplicate samples of leaves from Joshua trees and creosote bushes have also been collected. Duplicate samples of each type of plant at six locations, distributed approximately uniformly around the DAF, are being analyzed by gamma spectroscopy, and for tritium content of plant moisture. These locations coincide with those selected for soil moisture sampling, and are also indicated in Attachment A.11.

\subsection{RECORD KEEPING AND REPORTS}

\subsection{RECORDS}

\section{Monitoring of Flora and Fauna}

Data obtained from surveillance of plants and animals during pre-operational monitoring of the DAF are recorded on pre-printed data sheets. Data include site and transect descriptions, locations, enumeration of species, remarks on conditions, and any other parameters pertinent to the type of monitoring being performed. These data sheets are documents of record. Working copies will be made for temporary use, and the original data sheets will be stored in federal archives.

\section{Radiological Environmental Surveillance}

Sample collection and analyses are recorded by the Analytical Services Department (ASD) concurrently with records of other surveillances according to ASD Standard Operating Procedures. Sample collection data are recorded on standard forms that are permanently stored. The analytical data are recorded in bound laboratory notebooks that are also permanently stored, and radioactivity measurement data are stored in a laboratory computerized database management system, with backups, and maintained permanently.

Radioanalytical and instrument QAQC data are recorded in bound laboratory notebooks that are permanently stored. Measurement data for instrument calibrations are stored in the laboratory computerized database. Hardcopy records for instrument calibrations are kept in separate files during use, and are then archived. 


\subsection{REPORTS}

\section{Monitoring of Flora and Fauna}

The results of flora and fauna monitoring are compiled and published as Department of Energy Nevada Operations Office technical reports, such as References 8 and 9 herein. Summaries of these data are also published in each year's Annual Site Environmental Report (ASER).

\section{Radiological Environmental Surveillance}

The DAF pre-operational radiological environmental monitoring data will be published in a separate report, along with a description of the procedures used to collect the data, quality control measures taken to ensure data validity, and the degree to which the data met the Data Quality Objectives established in Attachment A.8.

Data for those parts of the DAF pre-operational radiological monitoring system that are incorporated into the permanent NTS environmental surveillance networks will be reported in the ASER along with the other surveillance data. 


\section{REFERENCES}

1. U. S. Department of the Interior, Fish and Wildlife Service,

May 20, 1992, Biological Opinion on Nevada Test Site Activities, letter 1-5-91-F-225 from David L. Hurl, Field Supervisor, Reno Field Office, Fish and Wildlife Service, to Nick C. Aquilina, Manager, Nevada Operations Office, U. S. Department of Energy.

2. U. S. Department of the Interior, Fish and Wildlife Service, April 13, 1994, Amendment to Biological Opinion for Nevada Test Site Activities, letter 1-5-91-F-225.AMD from David L. Harlow, State Supervisor, Reno Field Office, Fish and Wildlife Service, to Dr. Donald R. Elle, Director, Environmental Protection Division, Nevada Operations Office, U. S. Department of Energy.

3. U. S. Department of Energy, Environmental Assessment for Device Assembly Facility Operations, Nevada Test Site, Nye County, Nevada, Pre-Approval Draft, December 1994, DOE/EA-0971.

4. McArthur, R. D., Desert Research Institute, 1991, Radionuclides in Surface Soil at the Nevada Test Site, DOE Nevada Field Office Report DOE/NV/10845-02.

5. Black, S. C., Glines, W. M., and Townsend, Y. E., Editors, Reynolds Electrical \& Engineering Co., Inc., 1994, U. S. Department of Energy Nevada Operations Office Annual Site Environmental Report - 1993, Volume I, DOE Nevada Operations Office Report DOE/NV/11432-123.

6. Engineering-Science, 1990, Project Report of Air Quality Study at the Nevada Test Site, PE192.05, Engineering Science, Pasadena, Califomia.

7. Pre-construction Survey for DAF Facility at the Nevada Test Site, Nye County, Nevada, Inter-Office Memorandum dated 11 September 1994, from Dale Lee Gamer to Thomas P. O'Farrell, of EG\&G/Energy Measurements. Describes the pre-construction survey conducted Sept. 5-6, 1984, and cited in Reference 3.

8. Woodward, B. D., Hunter, R. B., Greger, P. D., and Saethre, M. S., Reynolds Electrical \& Engineering Co., Inc., 1995, The 1993 Baseline Biological Studies and Proposed Monitoring Plan for the Device Assembly Facility at the Nevada Test Site, DOE Nevada Operations Office Report DOE/NV/11432-163, in press.

9. Woodward, B. D., Hunter, R. B., Greger, P. D., and Saethre, M. S., Reynolds Electrical \& Engineering Co., Inc., 1995, The 1994 Baseline Biological Studies for the Device Assembly Facility at the Nevada Test Site, in preparation.

10. EG\&G/Energy Measurements, 1991, Biological Assessment of the Effects of the U. S. Department of Energy Field Office, Nevada, on the Threatened Desert Tortoise, written for the DOE Nevada Field Office for submission to the U. S. Department of the Interior, Fish and Wildlife Service, to provide the information needed by the Fish and Wildlife Service to issue its Biological Opinion.

11. EG\&G/Energy Measurements, The Northem Boundary of the Desert Tortoise Range on the Nevada Test Site, EGG 11265-1103, December 1994, by K. R. Rautenstrauch, G. A Brown, and R. G. Goodwin. 
12. EG\&G/Energy Measurements, 1991, The Distribution and Abundance of Desert Tortoises on the Nevada Test Site, U. S. Department of Energy Topical Report, EG\&G Santa Barbara Operations Report No. 10617-2081.

13. Henton, G. H., Reno, R. L., and Green, E., Desert Research Institute, 1984, A Class III Cultural Resources Reconnaissance of the Device Assembly Area (DAF). Frenchman Flat, Nye County, Nevada, Desert Research Institute Short Report SR090584-1.

14. Draft Safety Analysis Report for the Device Assembly Facility at the Nevada Test Site, DAF SAR-001-193-5394B, November 1994 (UCNI). Prepared for Raytheon Services Nevada by Mel Chew and Associates.

15. U. S. Department of Energy, General Environmental Protection Program, DOE Order 5400.1, Change 1, 1990. 

Table 5. Estimated Inventories of Major Manmade Radionuclides in NTS Surface Soil as of January 1,1990

Radionuclide Inventory (Ci)

\begin{tabular}{|c|c|c|c|c|c|c|c|c|c|}
\hline Area & ${ }^{241} \mathrm{Am}$ & ${ }^{238} \mathrm{Pu}$ & ${ }^{239,240} \mathrm{Pu}$ & ${ }^{60} \mathrm{Co}$ & ${ }^{137} \mathrm{Cs}$ & ${ }^{90} \mathrm{Sr}$ & ${ }^{152} \mathrm{Eu}$ & ${ }^{154} \mathrm{Eu}$ & ${ }^{155} \mathrm{Eu}$ \\
\hline 1 & 4.2 & 6.5 & 24. & 1.1 & 8.8 & 15. & 15. & 0.1 & 0.5 \\
\hline 2 & 2.9 & 8.6 & 22. & 1.2 & 24. & 46. & 14. & 0. & 0.4 \\
\hline 3 & 4.6 & 3.1 & 37. & 1.0 & 12. & 33. & 18. & 0.1 & 0.5 . \\
\hline 4 & 6.6 & 13. & 40. & 1.6 & 12. & 13. & 9.1 & 0. & 0.2 \\
\hline 5 & 0.6 & 0.1 & 4.8 & 0.6 & 0.4 & 0.9 & 10. & 0.2 & 0. \\
\hline 6 & 1.7 & 3.3 & 8.4 & 0.2 & 2.8 & 3.5 & 0. & 0 & 0. \\
\hline 7 & 2.2 & 0.6 & 16. & 1.0 & 5.2 & 9.2 & 22. & 0.2 & 0.3 \\
\hline 8 & 17. & 8.0 & 110. & 5.7 & 42. & 25. & 4.4 & 0. & 0.6 \\
\hline 9 & 4.2 & 2.2 & 89. & 0.7 & 8.7 & 13. & 23. & 0.2 & 0.3 \\
\hline 10 & 19. & 19. & 110. & 9.7 & 84. & 55. & 2.2 & 0.3 & 5.0 \\
\hline 11 & 3.3 & 0.5 & 29. & 0. & 0.5 & 0.3 & 0. & 0. & 0. \\
\hline 12 & 5.7 & 8.5 & 39. & 1.2 & 20. & 17. & 0. & 0. & 0. \\
\hline 15 & 8.0 & 7.8 & 63. & 0.3 & 19. & 22. & 0. & 0. & 0. \\
\hline 16 & 0.7 & 1.5 & 3.7 & 0.1 & 2.9 & 3.7 & 0. & 0. & 0. \\
\hline 17 & 2.8 & 4.5 & 18. & 1.0 & 15. & 19. & 0. & 0. & 0. \\
\hline 18 & 19. & 5.6 & 100. & 0.7 & 10. & 17. & 1.1 & 0.1 & 0.8 \\
\hline 19 & 21. & 32. & 140. & 1.1 & 36. & 31. & 0. & 0. & 0. \\
\hline 20 & 23. & 30. & 41. & 7.9 & 5.5 & 4.3 & 13. & 1.6 & 4.8 \\
\hline 25 & 0. & 0. & 0. & 0. & 0.2 & 0.1 & 0.4 & 0. & 0. \\
\hline 26 & 0. & 0. & 0. & 0. & 0. & 0. & 0. & 0 & 0. \\
\hline 30 & 3.2 & 4.5 & 14. & 0.8 & 1.5 & 1.3 & 0.7 & 0.1 & 0.2 \\
\hline Total & 150. & 160. & 910. & 35. & 310. & 330. & 130. & 2.8 & 14. \\
\hline
\end{tabular}

- $\quad{ }^{137}$ Cs was almost always present in measurable amounts, so the few ULVs were treated as valid data.

- $\quad{ }^{241} \mathrm{Am}$ and ${ }^{60} \mathrm{Co}$ were assumed to be present at one-half the ULV, as determined by inspection of the data. For example, if the ${ }^{241} \mathrm{Am}$ values in a region tended to be ULVs in the 25 to $35 \mathrm{nCi} / \mathrm{m}^{2}$ range, a value of $15 \mathrm{nCi} / \mathrm{m}^{2}$ was assumed.

- The three europium isotopes were found only relatively close to a GZ. They were assumed not to be present at all in regions where only ULVs were reported. Some previous inventory estimates for these radionuclides were therefore not used in making Table 5.

Inventories of the plutonium isotopes and ${ }^{90} \mathrm{Sr}$ were estimated from ${ }^{241} \mathrm{Am}$ and ${ }^{197} \mathrm{Cs}$ inventories using the radionuclide ratios from the nearest $G Z$ area.

Additional recalculation was necessary for Yucca Flat because the original estimates in Reports 1, 2, and 3 were not made for separate NTS areas. 


\section{ATTACHMENT A.2: ADAPTATION OF FIGURE 3 FROM REFERENCE 11:}

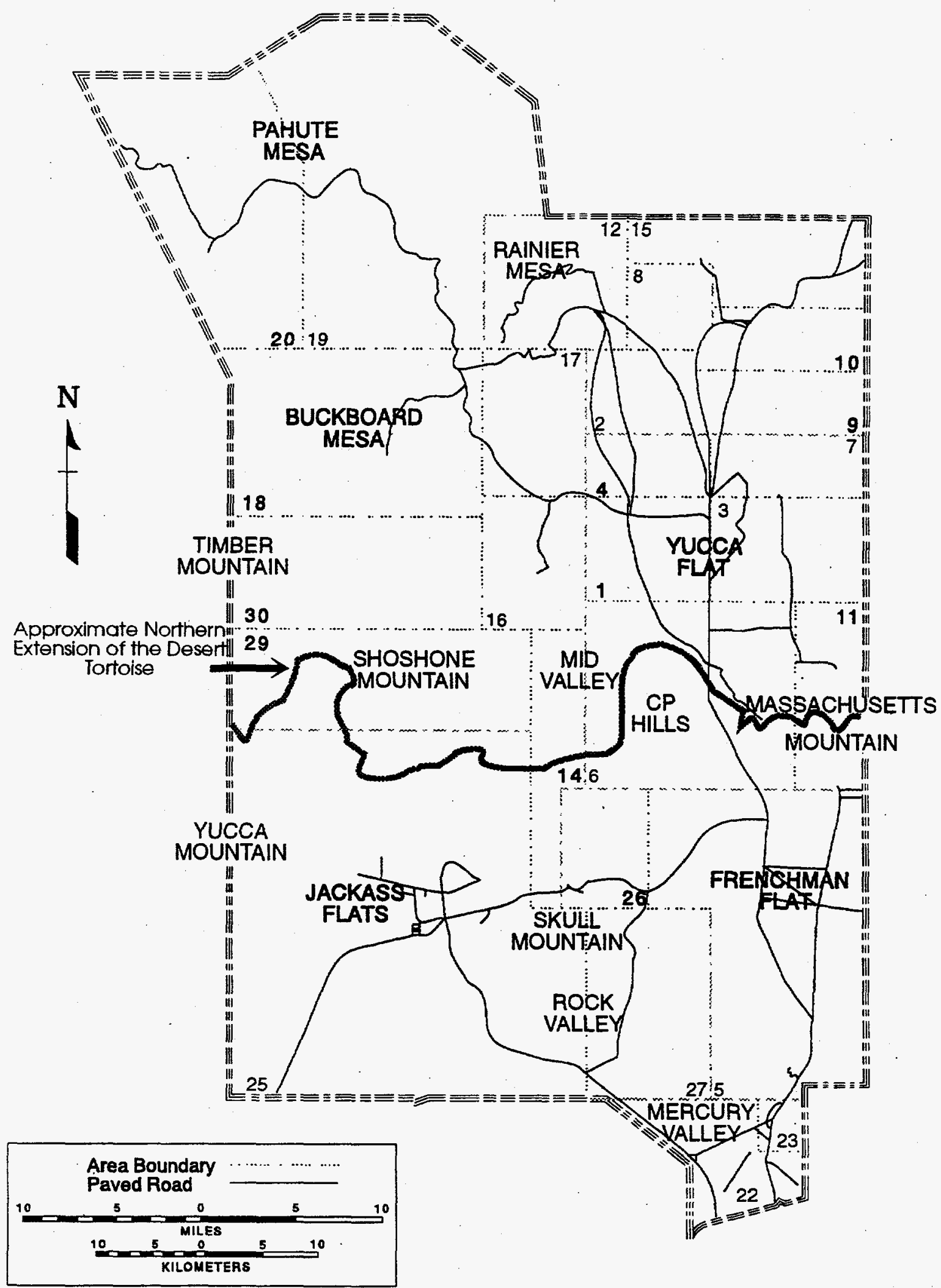

Figure 1. Northem Boundary of the Range of Desert Tortoise on the Nevada Test Site 


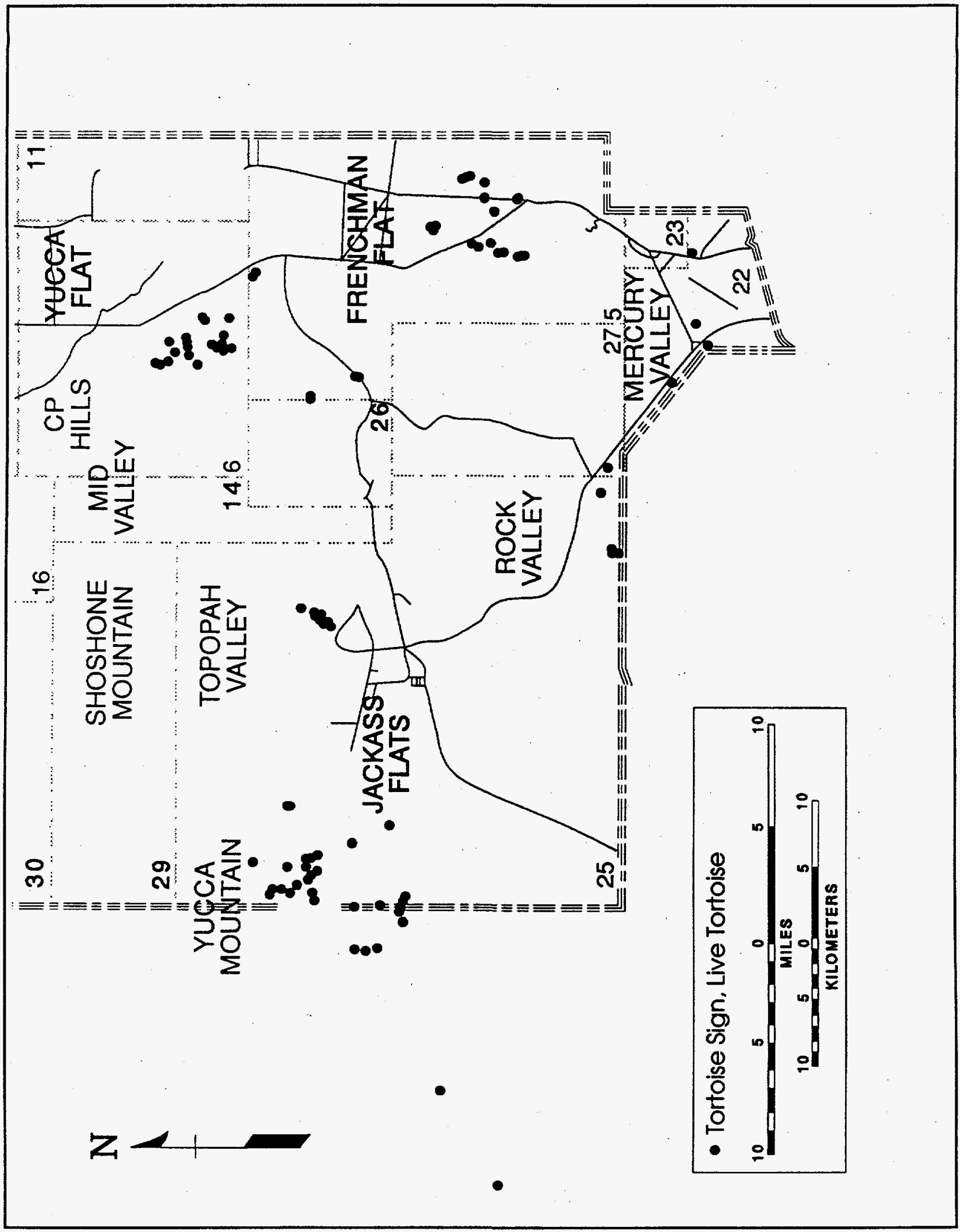

Figure 2. Tortoises found during Population and Impact Monitoring Studies on the NTS and Yucca Mountain during 1987-1990 
ATTACHMENT A.4: WIND ROSE FOR DAF

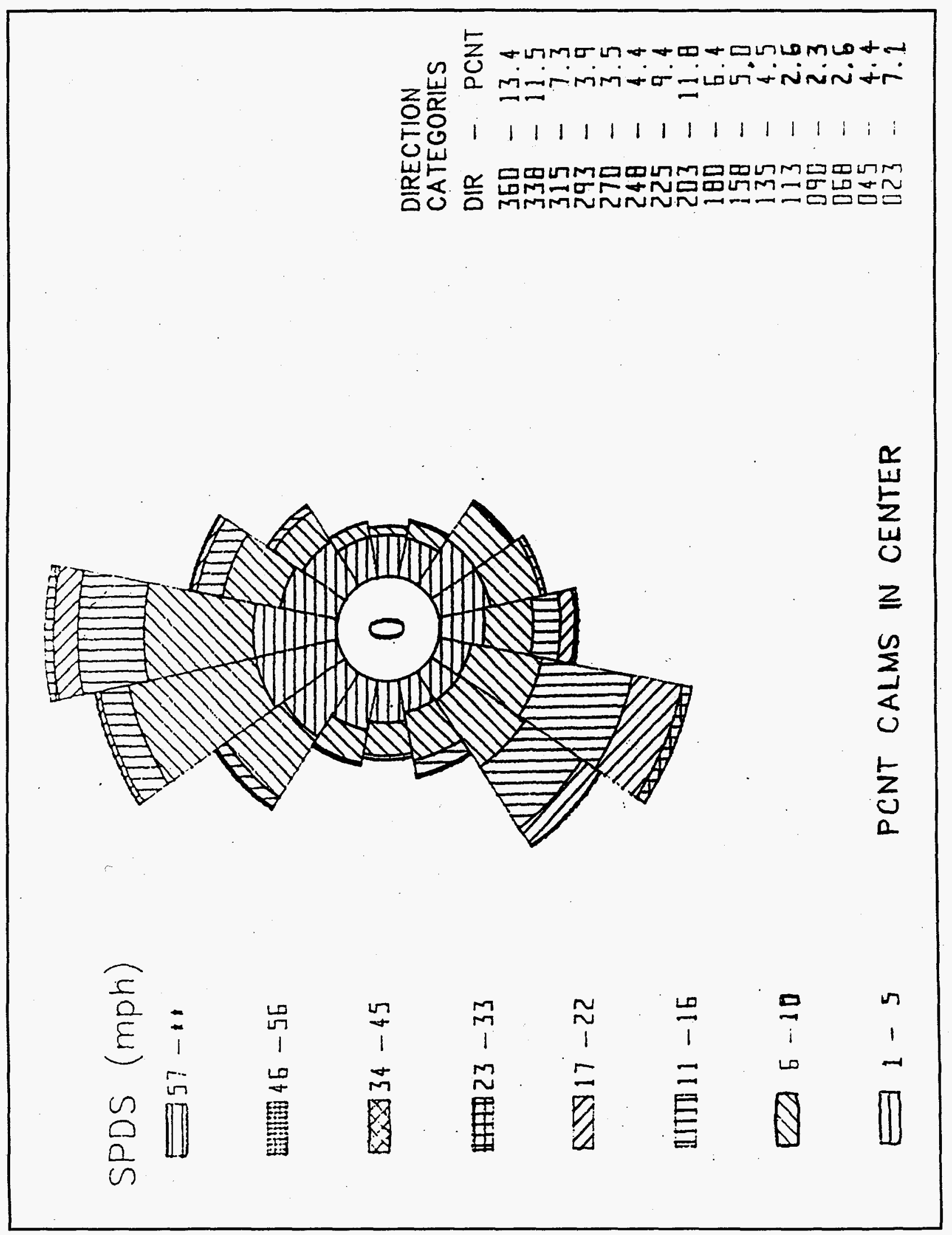

Figure 3. Wind Rose for DAF, "Annual" February 1993-July 1994 


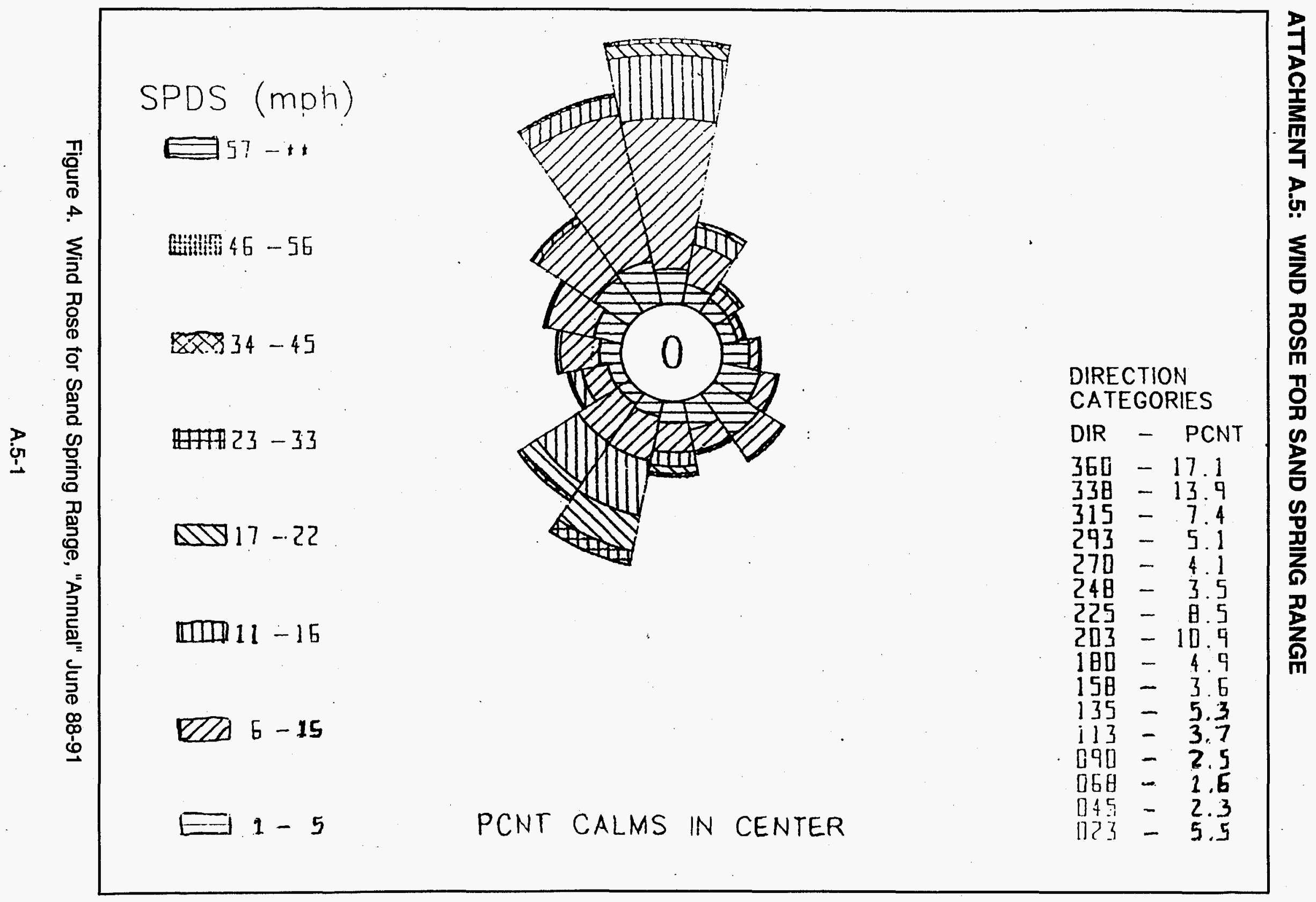




\section{ATTACHMENT A.6: SUMMARY OF RESULTS OF 1993 PRE-OPERATIONAL ECOLOGICAL MONITORING AROUND THE DAF}

\section{Ephemeral Plants}

Ephemeral plants were studied in four general locations: the vicinity of the paved access road; the scraped, graveled area west of the DAF; the undisturbed area north of the dike; and the area near the water tank.

Eighty nine species were identified in all, 26 at all four locations, 28 in only one. One species, Gilia capillaris, had not previously been reported for the NTS.

Densities were low on the graveled area, but the number of species present was unusually large: this suggests that the area had been cleared relatively recently, before the commonly dominant Salsola australis had a chance to force out many species. When comparing the side of the paved road to undisturbed terrain, almost twice as many species per square meter were found in the undisturbed terrain. When doing the same for the center of a dirt road leading to the water tank, the total number of species was the same (50 vs 49) as in an undisturbed control plot.

\section{Perennial Plants}

Perennial plants were measured on five sets of 20 plots arranged in five concentric bands in 20 directions around the DAF. All perennial plants within each $5 \times 2 \mathrm{~m}$ plot were censused. The Joshua tree and creosotebush were the largest contributors to volume and biomass. In terms of area covered, creosotebush, Krameria parvifolia, and white bursage dominated. A total of 23 perennial species were found in the one hundred $10 \mathrm{~m}^{2}$ plots, a number which is lower than expected, but unlikely to be due to the presence of the DAF. Areas near the DAF had fewer shrubs and higher ratio of live to dead shrubs than areas farther out; both of these phenomena can be attributed to extensive removal of shrubs during construction.

\section{Birds}

The DAF sewage ponds were used extensively by migratory birds and species nesting near the DAF. The ponds were also an area of heavy bird predation. Ravens made only occasional use of the sewage ponds.

Bird usage of the DAF sewage ponds during spring was low followed by heavy summer use. The three most abundant species observed during 1993 were mourning doves, house finches and black-throated sparrows. Doves were dominant through June and July, declining to zero by late September. Finches were numerous in May and early June, dropped to near zero by July, and returned in smaller numbers in the fall. Doves and finches used the ponds significantly more than a natural (control) habitat on all dates they were observed. In contrast, the black-throated sparrow was observed only in the control location until the end of June, when mid-moming temperatures began to exceed 25 degrees Celsius, while its usage of the sewage ponds during July greatly surpassed its usage of the control habitat.

During 1993, 39 bird species used the sewage ponds for resting, drinking or foraging. Thirteen of these were also seen in natural habitats. Eleven species of shorebirds and ducks 
were seen at the sewage ponds but not in other habitats. Raptors observed at the ponds were prairie falcon, red-tailed hawk and barn owl. Several barn owls and an American kestrel were removed from inside the DAF building in August. Thirty one bird species were observed in natural habitats near the DAF in 1993. Of these, 18 were not seen at the sewage ponds. Raptors sighted in nearby natural habitats were the American kestrel, osprey, golden eagle, red-tailed hawk, and Swainson's hawk.

\section{Mammals}

Three traplines of $1180 \mathrm{~m}$ each were set up, one along the paved road from the DAF to Mercury Highway (disturbed habitat), one from the east side of the sewage ponds to the southeast (mostly undisturbed, some localized disturbances), and one approximately $300 \mathrm{~m}$ north of the flood dike (essentially undisturbed). On each trapline 119 trap stations were located at $10 \mathrm{~m}$ intervals.

Nine species of small mammals were found, in a sample of 702 captures, during three nights in early June 1993. Merriam's kangaroo rat was most numerous at the two traplines south of DAF; the long-tailed pocket mouse was most numerous north of DAF. Sampling in early June gave about equal density of rodents along the first two traplines, and a significantly higher density along the third trapline in undisturbed terrain. The difference, however, may be due to the fact that the third line is located in somewhat different surroundings, where there are more Joshua trees and washes. The line along the paved road yielded a higher density nearer the DAF. Additional sampling in late June along the first two lines gave higher trap success for both, although animal abundance was similar to that for the earlier measurements.

One nighttime attempt was made to capture bats at the sewage ponds; due to rising winds only one bat (Pipistrellus hesperus) was caught, while several larger pale bats were observed but not caught. Other mammals observed were jackrabbits, at all three locations, and coyotes around the sewage ponds. Deer and mountain lion tracks were observed in the foothills west of the DAF in mid-summer.

\section{$\underline{\text { Reptiles }}$}

To investigate the effects of the paved road running from Mercury highway to the DAF, ten $20 \times 40 \mathrm{~m}$ plots were placed along the south eastem edge of the road, and ten control plots were placed in a similar vegetative community 300 to $1000 \mathrm{~m}$ from the paved road. Lizards found were noosed (when possible), measured, weighed, marked, and released. Plots were sampled one to three hours after sunrise during five days in late March and early April 1993 (spring) and again during five days in early August (summer).

The side-blotched lizard was the most common. There was a significantly greater number of side-blotched lizards in the control versus roadside areas during the spring; in the summer no significant difference in numbers was observed. However, in both cases, when the roadside areas are divided into two segments parallel to the road, one from 0 to $10 \mathrm{~m}$ from road center (this segment contains about $4 \mathrm{~m}$ of pavement and $6 \mathrm{~m}$ of graded shoulder), and the other from 10 to $20 \mathrm{~m}$ from road center (this segment contains $0-2 \mathrm{~m}$ of graded shoulder and $10-8 \mathrm{~m}$ of vegetation at the road berm), it was found that all the lizards observed were in the berm segment. Thus, within the berm segment of the disturbed plots, the density of sideblotched lizards in the spring was approximately equal to that in the control areas, and in the 
summer the density in the berm area was more than double that in the control area, indicating a positive local effect of road construction on the lizard population density.

During the spring, females were present in significantly greater numbers in the roadside area. In the summer no sexual differentiation between roadside and control areas was observed.

The effects of the flood diversion ditch located upslope of the DAF on lizard populations were investigated. Six $10 \times 50 \mathrm{~m}$ plots were located in the ditch bottom, and twelve were placed as control plots, of which six were located on arroyo bottoms and six on flat areas between arroyos. One species, the zebra-tailed lizard; was dominant in the flood-dike ditch, and uncommon elsewhere.

Other methods used were walking lizard transects to examine more mobile species, and timed surveys, both examining disturbed land surface around the DAF and undisturbed areas farther away. Aside from a general correlation between number of lizard species and number of individual lizards with the vegetated area near the road, the primary benefit of these methods was to obtain information on the variety and spatial distribution of reptile species present. One desert tortoise was seen on two occasions, in May 1993 approximately $300 \mathrm{~m} \mathrm{NW}$ of the DAF ditch, and in September approximately $100 \mathrm{~m}$ east of the DAF buildings on the paved access road. Tortoises or their remains were seen in all areas except the DAF disturbed area. The remains were found mostly north and west of the DAF buildings, with some also found to the south. 


\section{ATTACHMENT A.7: PERMITTING REQUIREMENTS}

Following is a description of the principal permits required for the DAF, including source regulations and present compliance status.

- 40 CFR Part 61 Subpart H - National Emissions Standards for Emissions of

Radionuclides Other Than Radon From Department of Energy Facilities.

- $\quad$ No permits required.

- Monitoring, test procedures, compliance, and reporting requirements are specified.

- Pre-operational monitoring, CAP88-PC.

- $\quad 10$ CFR Part 1021 - National Environmental Policy Act, Implementing Procedures and SEN-15-90. 40 CFR Parts 1500-1508 - National Environmental Policy Act, Council of Environmental Quality.

- $\quad$ No permits required.

- $\quad$ Determined by the Secretary of Energy to require an Environmental Assessment, for the DAF, which will soon be issued in final form.

- $\quad$ NAC 445.430-846 - Air Quality Permits.

- The DAF is presently included under the site-wide permit for the NTS, Nevada Air Quality Operating Permit 2743, which expires in 1998. This permit allows DOE/NV to engage in construction or other activity resulting in minimal variable surface area disturbances. Under this permit, disturbances encompassing areas larger than five acres must be reported.

NAC 445.244-262 - Public Water Systems.

- The DAF is presently included under the Area 6 permit for the NTS, Nevada State Division of Health Public Water System Permit NY-5000-12NCNT, which expires on September 30, 1995.

NAC 444.570-748 - Solid Waste Regulations.

- In the past, no permit was required.

- In March of 1994 the state of Nevada was granted authority by the EPA to institute a solid waste management program. This information was communicated by the state to solid waste disposal sites in Nevada, including the NTS. A requirement of the program is that before a new disposal site can open, a permit to operate must be obtained from the state Solid Waste Management Authority or the Nevada Division of Environmental Protection/Bureau of Federal Facilities. For those facilities already in operation, such as those on the NTS, they may continue to operate, but must also apply for a permit.

No deadline was given for obtaining the permit. However, DOE has filed a Notice of Intent with the state Solid Waste Management Authority and the Nevada Division of Environmental Protection/Bureau of Federal Facilities to apply for a permit to continue using the Area 23 disposal facility for disposal of all NTS generated ordinary solid waste, including that generated by the DAF. 
The U10C facility in Area 9 would continue to be used for disposal until October 1995. After that the Area 23 facility would be used for construction debris until a barrier layer can be installed at $\mathrm{U} 10 \mathrm{C}$, after which $\mathrm{U} 10 \mathrm{C}$ would be reopened for the disposal of construction debris only. The REECo Waste Operations Department will prepare the required permit application.

- $\quad$ An Environmental Assessment is being prepared for a site-wide solid waste disposal system at the NTS.

- DOE Order 5820.2A - Radioactive Waste Management. NVO-325, Rev.1, "Nevada Test Site Defense Waste Acceptance Criteria, Certification, and Transfer Requirements."

- $\quad$ No permits required.

- DAF would dispose of low level radioactive waste at the NTS Area 5 Radioactive Waste Management Site (RWMS) under the terms of NVO-325.

- $\quad 40$ CFR Part 190-299. NAC 444.842-960 - Hazardous Waste Regulations.

- The following hazardous waste management services would be available to the DAF:

- $\quad$ The NTS has been assigned EPA Identification Number NV3890090001 as a generator of hazardous waste.

- On January 11, 1995, the 45 day comment period began for the DOE application to the state of Nevada Division of Environmental Protection (NDEP) for a permit to allow the NTS to function as a TSD facility for storage of hazardous waste in Area 5 for up to one year, and for the treatment of explosives at the Area 11 Explosive Ordnance Disposal facility.

- The above permit application also requests approval for the operation of a mixed waste disposal unit at the Area 5 RWMS, but the permit for mixed waste has not yet been prepared by NDEP for review and approval. Currently, mixed waste is stored on a pad in Area 5 in compliance with an agreement between DOE/NV and NDEP, drafted in January 1994.

- NAC 445.753 - Open Bum Permit

In the past, DOE has applied annually to the state of Nevada Division of Environmental Protection for a Permit for Open Burning in Area 27, for the purpose of burning class " $\mathrm{A}$ " combustibles that have been in contact with high explosives. This permit has been granted, and renewed on an annual basis. A similar procedure will be followed to deal with any such waste generated by the new Device Assembly Facility.

- NAC 445.199-241 - Water Pollution Regulations

- The DAF sewage pond and sewage disposal system are presently covered under Water Pollution Control General Permit GNEV93001, issued by the Nevada Division of Environmental Protection for all sewage ponds on the NTS, and valid 
until January 31, 1999. Also, a stormwater conveyance and diversion structure has been constructed to protect the DAF and supporting structures, including the sewage pond, from storm runoff. In addition, the design of the sewage system incorporates a raised dike, reducing the probability of dispersion of sewage pond waters by floodwaters during intense rainstorms.

40 CFR Part 280, NAC 459.992-998, 590.730-780 - Underground Storage Tank Regulations

- The Nevada State Environmental Commission has elected not to require storage tank permits. However, in compliance with federal and state regulations, the state of Nevada was notified on October 17, 1991, by means of a letter from D. Elle, DOE/NV Environmental Protection Division, to Paul J. Liebendorfer, Nevada Division of Environmental Protection, of the existence and characteristics of the five storage tanks at the DAF, 6-DAF-1, $-2,-3,-4$, and -5 . The DAF tanks were included in a notification list which included 116 underground storage tanks. 


\section{ATTACHMENT A.8 DATA QUALITY OBJECTIVES FOR DAF PRE-OPERATIONAL MONITORING}

\section{RADIOLOGICAL ENVIRONMENTAL SURVEILLANCE}

To assure that the radiological data from the analyses of environmental samples is of acceptable quality, data quality objectives (DQOs) are defined below as a guide. The DQOs are defined for the Analytical Services Department (ASD) of Reynolds Electrical \& Engineering Co., Inc., (REECo), since this is the organization responsible for the performing sampling and analyses.

The DQOs are defined in terms of representativeness, comparability, completeness, precision, accuracy and detectability. The first three are defined for all networks and analyses. Precision, accuracy and detectability are defined for each analysis or radionuclide.

\section{REPRESENTATIVENESS}

Representativeness is the degree to which a sample is truly representative of the sampled medium, i.e., the degree to which measured analytical concentrations represent the concentrations in the medium being sampled. Representativeness also refers to whether the locations and frequency of sampling are such that calculational models will lead to a correct estimate of potential effective dose equivalent to a member of the public when measured radioactivity concentrations are input into the model. Factors which were considered in designing this monitoring plan include location and types of potential sources, historical and operational knowledge of isotopes and pathways of concern, effects of wind and weather, extensive historical meteorological data, geological, hydrological, and topographical data, and locations of human populations.

\section{COMPARABILITY}

Comparability refers to the degree of confidence and consistency we have in our analytical results. To achieve comparability in measurement data, sample collection and handling, laboratory analyses, and data analysis and validation are performed in accordance with established Standard Operating Procedures. Standard reporting units and a consistent number of significant digits are used. Instruments are calibrated using National Institute of Standards and Technology (NIST)-traceable sources. Each batch of field samples is accompanied by a blank and a spiked sample with known quantities of the compound(s) of interest. Radioactivity measurements are made of prepared field samples and accompanying instrument standards and blanks. Data acquisition, numerical processing, and data validation have been carefully developed and thoroughly tested. Extensive quality assurance measures are used for all analytical processes. REECo ASD laboratories participate in several intercomparison programs where results can be compared with those of the sponsor laboratory and those of other participating laboratories.

\section{COMPLETENESS}

Completeness is defined as the percentage of samples collected versus those which had been scheduled to be collected, or the percentage of valid analysis results versus the results which would have been obtained if all samples had been obtained and correctly analyzed. 
Realistically, samples can be lost during storage, handling, preparation, and analysis, or not collected as scheduled. Data entry or transcription errors can be made. The REECo ASD completeness objectives have been set at 90 percent for sample collection and 90 percent for analyses.

\section{PRECISION}

Precision is determined by comparing results for duplicate samples of particulates in air, tritiated water vapor, soil, vegetation, and water samples. The precision objectives which follow are a function of the concentration of radioactivity in the samples and the difficulty in obtaining representative samples. These objectives give precision goals expressed as a percent.

Precision Objectives for Air, Tritiated Water Vapor, and Water Samples:

\begin{tabular}{|c|c|c|}
\hline Analysis & Conc. $>10 \mathrm{MDC}$ & $4 \mathrm{MDC} \leq$ Conc. $\leq 10 \mathrm{MDC}$ \\
\hline Gross Beta & \pm 30 & \pm 60 \\
\hline Gamma Spectroscopy & \pm 30 & \pm 60 \\
\hline Tritium & \pm 30 & \pm 60 \\
\hline Alpha Spectroscopy & \pm 20 & \pm 50 \\
\hline
\end{tabular}

Precision Objectives for Soil and Vegetation Samples:

Analysis

Conc. $>10 \mathrm{MDC}$

$\pm 30$

$\pm 30$

$\pm 30$
$4 \mathrm{MDC} \leq$ Conc. $\leq 10 \mathrm{MDC}$

$\pm 100$

$\pm 100$

$\pm 100$

\section{ACCURACY}

Accuracy refers to how well we can measure the true value of a given quantity. Assessments of accuracy are done by performing measurements on special quality assurance samples prepared, using stringent quality control, by laboratories which specialize in preparing such samples. The REECo ASD Radioanalytical Laboratory participates in such interlaboratory comparison programs with the DOE Environmental Measurements Laboratory and the EPA Environmental Monitoring Systems Laboratory - Las Vegas. Accuracy objectives follow; they are expressed as a percent.

\begin{tabular}{lcc} 
Analysis & Conc. $>10 \mathrm{MDC}$ & $4 \mathrm{MDC} \leq$ Conc. $\leq 10 \mathrm{MDC}$ \\
\cline { 2 - 3 } Gross Beta & \pm 20 & \pm 50 \\
Gamma Spectroscopy & \pm 20 & \pm 50 \\
Tritium & \pm 20 & \pm 50 \\
Alpha Spectroscopy & \pm 20 & \pm 50
\end{tabular}




\section{DETECTABILITY}

Detectability for a given isotope and analytical process is a function of sample type, sample size, background activity, efficiency of recovery, counting time, instrument efficiency, and other details of the preparation and measurement process. It is usually expressed as a minimum detectable activity (MDA) or a minimum detectable concentration (MDC). Following are representative detectability objectives, expressed as MDAs, in picocuries.

\section{Sample Type}

\section{Analysis}

$$
\text { Air }
$$

3.8

140

4.1

140

Tritium

Alpha Spectroscopy

${ }^{241} \mathrm{Am},{ }^{234} \mathrm{U},{ }^{235} \mathrm{U},{ }^{238} \mathrm{U}$

${ }^{238} \mathrm{Pu},{ }^{239+240} \mathrm{Pu}$

.042

${ }^{90} \mathrm{Sr}$
140

4.1

Soil

2.6

.05

.08
Vegetation

\section{ECOLOGICAL MONTORING}

\section{DQOS FOR SPECIES PRESENCE OR ABSENCE}

\section{REPRESENTATIVENESS}

It is expected that more than 90 percent of the species censused will be representative of the area studied. That is, more than 90 percent of the species encountered will be native to the area around the DAF, and will survive and reproduce there.

\section{COMPARABILITY}

Comparability to results of similar studies should be high, greater than 95 percent, because the techniques used are generally similar in all such studies.

\section{COMPLETENESS}

Credible sightings and trapped animals should include at least the following proportions of species occurring on the site:
Lizards
$>90$ percent
Mammals
$>50$ percent
Perennial plants
$>95$ percent
Annual plants
$>25$ percent per year. 


\section{PRECISION}

The objective is 100 percent accuracy on individual sightings of plants or trapped animals, so the precision objective is also 100 percent for these cases. Precision and accuracy for bird, mammal and reptile sighting in natural habitat is highly dependent on the circumstances; overall, the precision objective for all such sightings is set at 90 percent.

\section{ACCURACY}

The objective is to properly identify all species captured. For sightings of birds, mammals and reptiles in natural habitat, the objective is to properly identify the species in at least 90 percent of the sightings.

\section{DETECTABILITY}

The limits of detectability are approximately:

$\begin{array}{ll}\text { Lizards } & 1 / \text { ha } \\ \text { Mammals } & 1 / \text { ha } \\ \text { Perennial plants } & 1 / \text { ha } \\ \text { Annual plants } & 10 / \mathrm{ha}\end{array}$

\section{DQOS FOR MONITORING PLOTS}

\section{REPRESENTATIVENESS}

For the common species monitored the densities measured would vary on the order of 50 percent on similar plots, due to habitat variation. It is expected that trends in population densities will be representative of that part of a broad area surrounding the plot which has similar topography, geology, hydrology, weather conditions, and history of human intervention.

\section{COMPARABILITY}

Repeat censuses at a single location are highly comparable. Increases or decreases in measured densities of lizards, mammals, and plants are indicative of real changes in population, rather than measurement errors.

\section{COMPLETENESS}

It is expected that all monitoring censuses will be completed.

\section{PRECISION}

- Precision is density dependent. For normal densities the objectives are:

\section{At 95 percent confidence level}

Lizards (side-blotched, spring density) $\quad \pm 20$ percent of mean Mammals (common species, summer density) \pm 35 percent of mean Perennial plants (at a given location) $\quad \pm 5$ percent of mean Annual plants (given location, when active) \pm 40 percent of mean 


\section{ACCURACY}

Historical studies have shown that the techniques to be used are highly accurate, because densities of the monitored species are based on capture or observation of 95-100 percent of the animals and plants present at a site.

\section{DETECTABILITY}

Limits of detection for monitored species are approximately:

Lizards (side-blotched)

2/ha

Common mammals

$1 /$ ha

Perennial plants

100/ha

Annual plants

10/ha 


\section{ATTACHMENT A.9: ESTIMATED COSTS}

Following is an overview of the distribution of effort and cost for the development of this Plan, for the monitoring, and for the analysis and reporting of the resultant data.

FY 1993

$\begin{array}{lcccc}\begin{array}{l}\text { Preop. } \\ \text { Plan }\end{array} & \begin{array}{l}\text { Radiological } \\ \text { Monitoring }\end{array} & \begin{array}{l}\text { Radiological } \\ \text { Reports }\end{array} & \begin{array}{l}\text { Biological } \\ \text { Monitoring }\end{array} & \begin{array}{l}\text { Biological } \\ \text { Reports }\end{array} \\ \$ 9.7 \mathrm{~K} & - & - & \$ 60.3 \mathrm{~K} & \$ 7.1 \mathrm{~K}\end{array}$

Total FY 1993 Costs: $\quad \$ 77.1 \mathrm{~K}$

FY 1994

$\begin{array}{llcll}\begin{array}{l}\text { Preop. } \\ \text { Plan }\end{array} & \begin{array}{l}\text { Radiological } \\ \text { Monitoring }\end{array} & \begin{array}{l}\text { Radiological } \\ \text { Reports }\end{array} & \begin{array}{l}\text { Biological } \\ \text { Monitoring }\end{array} & \begin{array}{l}\text { Biological } \\ \text { Reports }\end{array} \\ \$ 25.2 \mathrm{~K} & \cdot \$ 112.4 \mathrm{~K} & \cdot- & \$ 51.5 \mathrm{~K} & \$ 55.4 \mathrm{~K}\end{array}$

Total FY 1994 Costs: $\quad \$ 244.5 \mathrm{~K}$

FY 1995 (Estimated)

$\begin{array}{lllcl}\begin{array}{l}\text { Preop. } \\ \text { Plan }\end{array} & \begin{array}{l}\text { Radiological } \\ \text { Monitoring }\end{array} & \begin{array}{l}\text { Radiological } \\ \text { Reports }\end{array} & \begin{array}{l}\text { Biological } \\ \text { Monitoring }\end{array} & \begin{array}{l}\text { Biological } \\ \text { Reports }\end{array} \\ \$ 4.1 \mathrm{~K} & \$ 18.8 \mathrm{~K} & \$ 7.8 \mathrm{~K} & - & \$ 19.0 \mathrm{~K} .\end{array}$

Total FY 1994 Costs:

$\$ 49.7 \mathrm{~K}$

\section{Discussion}

Much of the development of the Pre-operational Environmental Monitoring Plan was done concurrently with the monitoring process, with adjustments being made to overcome obstacles encountered in the field. The biological portion of the Plan was developed early in the process, with minor modifications added as monitoring was carried out. The major biological baseline monitoring effort took place during the spring and summer of 1993 (the natural biological monitoring period); the corresponding report and development of a proposed biological baseline monitoring plan took place in the winter months, in FY 1994. Additional biological monitoring was performed during the spring and summer of 1994. The 1994 report is being prepared at the present time.

Part of the radiological baseline monitoring was initiated in October of 1993, with the establishment of the two air sampling and two tritiated water vapor sampling stations. One of the air sampling stations had to be operated with a diesel fuel powered electrical generator, because of the lack of an altemate power source. Air sampling was terminated on January 4 , 1995. 
Routine sewage pond sampling was begun in October of 1994. Sewage sampling will continue on a quarterly basis for one year, and after that on an annual basis as part of the routine radiological sampling schedule for NTS sewage ponds.

Soil and vegetation samples were taken near the end of 1994. Soil moisture sampling is being performed at the present time. Several of the air, soil and vegetation analyses remain to be carried out.

Once all the radiological samples have been analyzed, and the data has been reviewed, the Environmental Section of REECo's Analytical Services Department will publish a report on the data gathered, and an analysis of the extent to which the DQOs established in Attachment A.8 were met.

In the process of producing the final report on the radiological baseline data for the DAF, any costs incurred beyond those presently budgeted for will be covered by the Environmental Monitoring budget, as these results contribute to our general knowledge of radiological conditions in the NTS environment.

The sampling and analysis program described in this Plan are considered sufficient and appropriate for establishing baseline data for the area around the Device Assembly Facility. Once completed, it will be considered that future monitoring of radiological conditions around the DAF, or due to operation of the DAF, should be dealt with as part of the permanent NTS radiological Environmental Surveillance Program.

Additional monitoring may be warranted in the future, depending on the operations undertaken in the DAF. At that time the situation will be assessed, and approval will be obtained from DOE/NV/EPD for any additional monitoring deemed necessary. 
ATTACHMENT A.10: MAP SHOWING AIR SAMPLER AND TRITIATED WATER VAPOR SAMPLER LOCATIONS

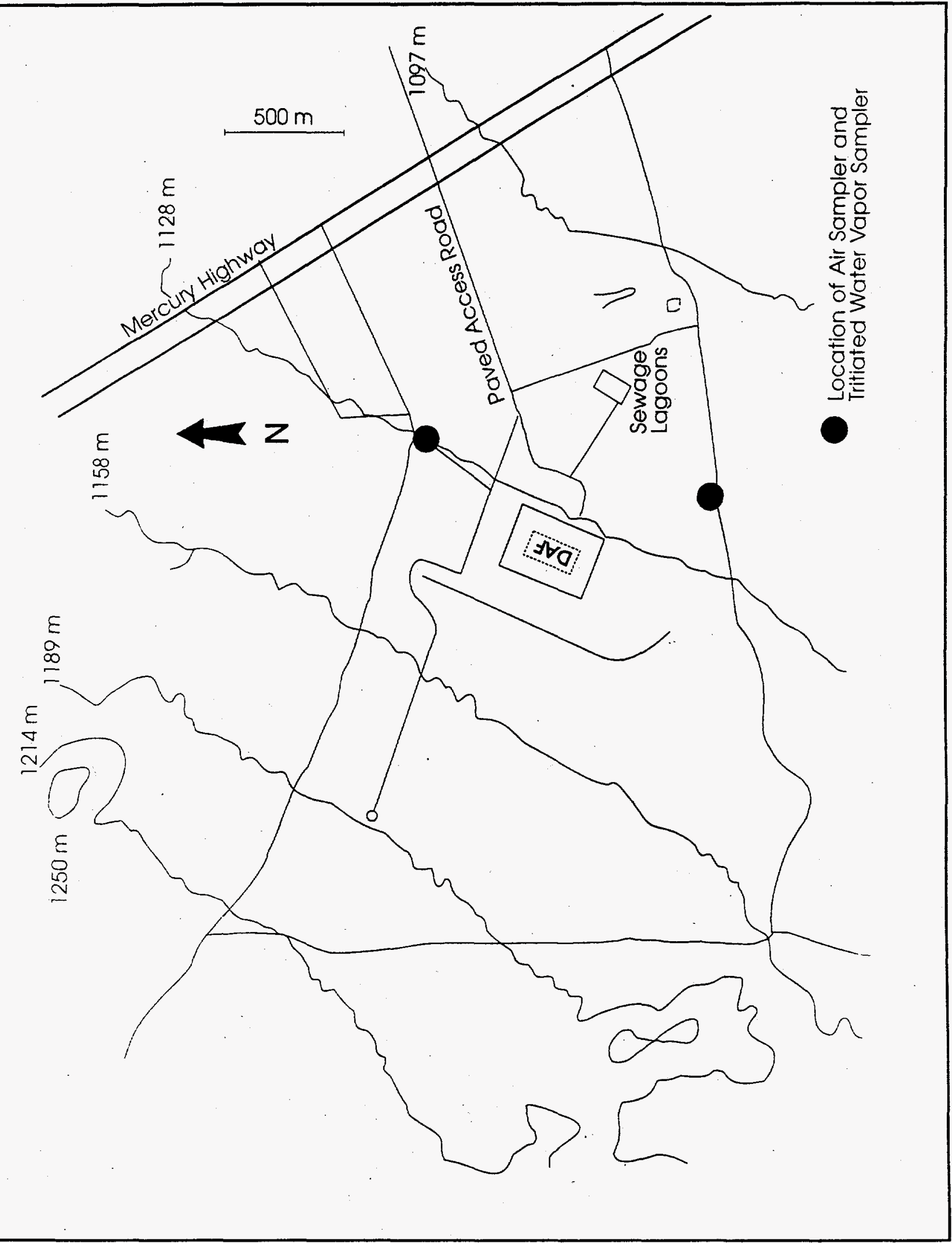

Figure 5. Air Sampler and Tritiated Water Vapor Sampler Locations 


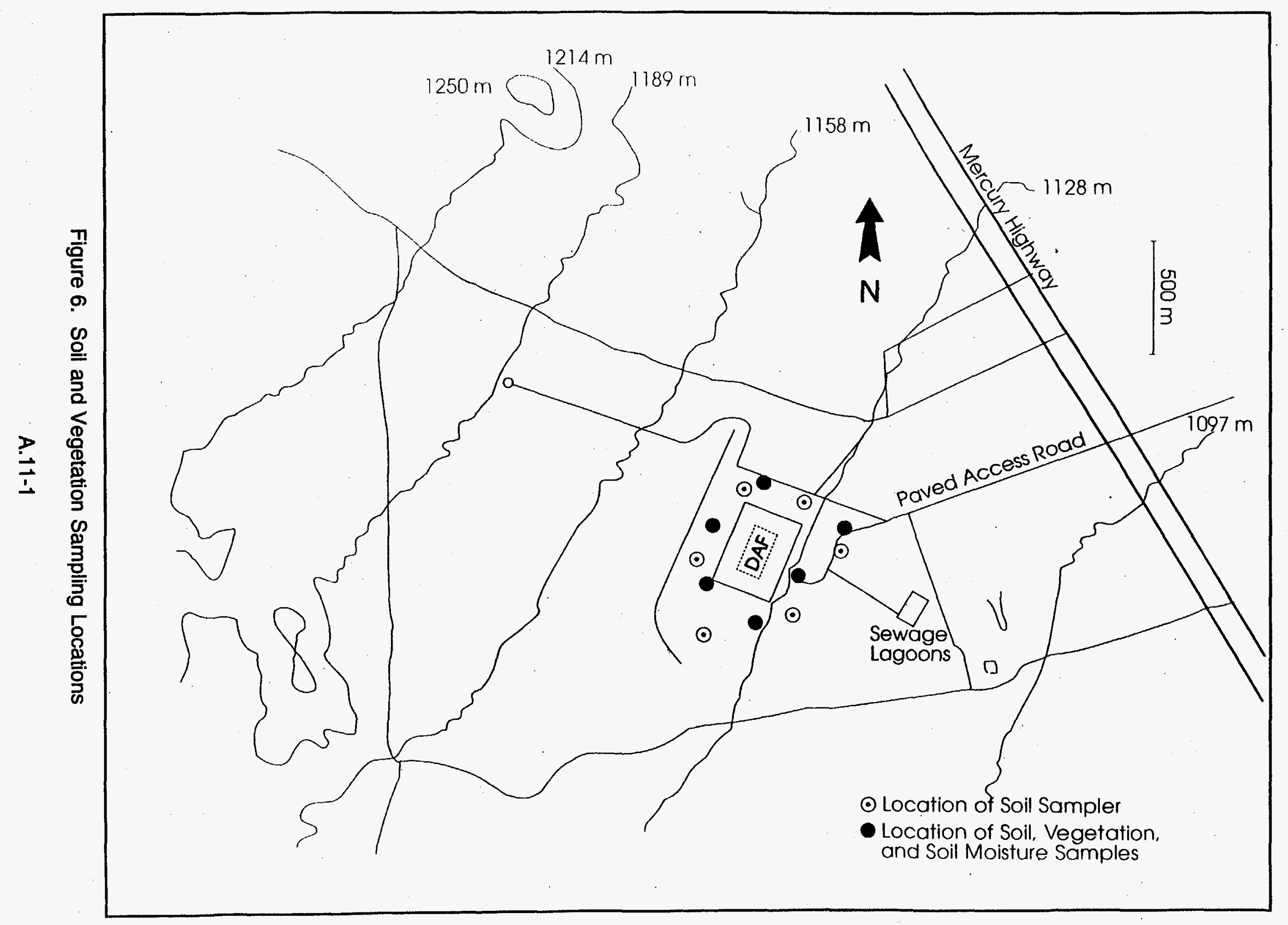

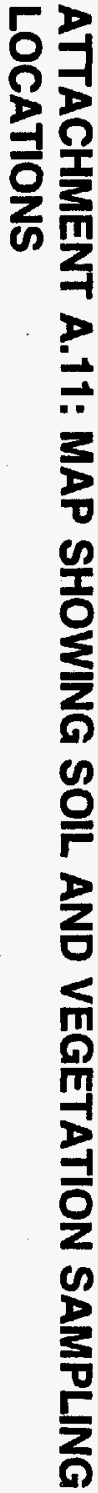




\section{DISTRIBUTION LIST}

EPA

Director, National Exposure Research Laboratory, U.S. Environmental Protection Agency, Post Office Box 93478, Las Vegas, NV 89193-3478, M/S 513

Director, Characterization Research Division, U.S. Environmental Protection Agency, Post Office Box 93478, Las Vegas, NV 89193-3478, M/S 513

A. A. Mullen, Characterization Research Division, U.S. Environmental Protection Agency, Post Office Box 93478, Las Vegas, NV 89193-3478, M/S 513

LANL

Resident Manager, Los Alamos National Laboratory, P. O. Box 0, Mercury, NV 89023 M/S 900

Section Leader, ES-12 NTS, Los Alamos National Laboratory, P. O. Box 0, Mercury, NV 89023 M/S 900

Radiological Control Manager, Los Alamos National Laboratory, P. O. Box 0, Mercury, NV $89023 \mathrm{M} / \mathrm{S} 900$

R. L. Higgs, Los Alamos National Laboratory, P. O. Box 0, Mercury, NV 89023 M/S 900

C.F. Eberhart, Los Alamos National Laboratory, Post Office Box 1663, Los Alamos, NM 87545, M/S F670 (2)

E. H. Essington, Los Alamos National Laboratory, Post Office Box 1663, Los Alamos, NM 87545, M/S J495

\section{LLNL}

Resident Manager, Lawrence Livermore National Laboratory, Post Office Box 45, Mercury, NV 89023, M/S 777

Environment, Safety \& Health Group Leader, Lawrence Livermore National Laboratory, Post Office Box 45, Mercury, NV 89023, M/S 777

Radiological Control Manager, Lawrence Livermore National Laboratory, Post Office Box 45, Mercury, NV 89023, M/S 777

S. E. Patton, Environmental Science Division L-524, Lawrence Livermore National Laboratory, Post Office Box 808, Livermore, CA 94551

L. Anspaugh, Risk Sciences Center, L-453, Lawrence Livermore National Laboratory, Post Office Box 808, Livermore, CA 94551 
$\underline{\text { SNL }}$

Resident Manager, Sandia National Laboratories, Post Office Box 38, Mercury, NV 89023

J. H. Metcalf, Sandia National Laboratories, Post Office Box 38, Mercury, NV 89023, M/S 944

$\underline{\text { DNA }}$

D. A. Bedsun, Defense Nuclear Agency, Post Office Box 98539, Las Vegas, NV 89193-8518 M/S 573

\section{EG\&G}

Librarian, EG\&G Energy Measurement Group Inc., Post Office Box 1912, Las Vegas, NV $89125 \mathrm{M} / \mathrm{S}$ 570/C-52

J. P. Maddox, EG\&G Energy Measurement Group Inc., Post Office Box 1912, Las Vegas, NV 89125, M/S 570/C1-105

P. D. Greger, EG\&G Energy Measurement Group Inc., Post Office Box 1912, Las Vegas, NV 89125, M/S 570/C1-105

R. B. Hunter, EG\&G Energy Measurement Group Inc., Post Office Box 1912, Las Vegas, NV 89125, M/S 570/C1-105

T. P. O'Farrell, EG\&G Energy Measurement Group Inc., Post Office Box 1912, Las Vegas, NV 89125, M/S 570/Ci-105

W. K. Ostler, EG\&G Energy Measurement Group Inc., Post Office Box 1912, Las Vegas, NV $89125, \mathrm{M} / \mathrm{S}$ 570/C1-105

M. B. Saethre, EG\&G Energy Measurement Group Inc., Post Office Box 1912, Las Vegas, NV 89125, M/S 570/C1-105

C. A. Wills, EG\&G Energy Measurement Group Inc., Post Office Box 1912, Las Vegas, NV 89125, M/S 570/C1-105

B. D. Woodward, EG\&G Energy Measurement Group Inc., Post Office Box 1912, Las Vegas, NV $89125, \mathrm{M} / \mathrm{S} 570 / \mathrm{C} 1-105$

\section{REECO}

Manager, Reynolds Electrical \& Engineering Co., Inc., Post Office Box 98521 , Las Vegas, NV 89193-8521, M/S 555

Manager, Environmental Management Division, Reynolds Electrical \& Engineering Co., Inc., Post Office Box 98521, Las Vegas, NV 89193-8521, M/S 417 (2)

Manager, Waste Management Department, Reynolds Electrical \& Engineering Co., Inc., Post Office Box 98521, Las Vegas, NV 89193-8521, M/S 501 


\section{Distribution List, cont.}

F. D. Ferate, Analytical Services Section, Reynolds Electrical \& Engineering Co., Inc., Post Office Box 98521, Las Vegas, NV 89193-8521, M/S 708

R. F. Grossman, Analytical Services Section, Reynolds Electrical \& Engineering Co., Inc., Post Office Box 98521, Las Vegas, NV 89193-8521, M/S 776

A. L. Latham, Analytical Services Section, Reynolds Electrical \& Engineering Co., Inc., Post Office Box 98521, Las Vegas, NV 89193-8521, M/S 708

O. L. Haworth, Analytical Services Section, Reynolds Electrical \& Engineering Co., Inc., Post Office Box 98521, Las Vegas, NV 89193-8521, M/S 612

B. S. Hooda, Analytical Services Section, Reynolds Electrical \& Engineering Co., Inc., Post Office Box 98521, Las Vegas, NV 89193-8521, M/S 776

Records Center, Reynolds Electrical \& Engineering Co., Inc., Post Office Box 98521, Las Vegas, NV 89193-8521, M/S 551

Central Files, Reynolds Electrical \& Engineering Co., Inc., Post Office Box 98521, Las Vegas, NV 89193-8521, M/S 530

R. R. Kinnison, Analytical Services Section, Reynolds Electrical \& Engineering Co., Inc., Post Office Box 98521, Las Vegas, NV 89193-8521, M/S 417

H. F. Kerschner, Health Protection Department, Reynolds Electrical \& Engineering Co., Inc., Post Office Box 98521, Las Vegas, NV 89193-8521, M/S 709

M. E. DeMarre, Health Protection Department, Reynolds Electrical \& Engineering Co., Inc., Post Office Box 98521, Las Vegas, NV 89193-8521, M/S 548

Manager, Environment, Safety, Health \& Quality Division, Reynolds Electrical \& Engineering Co., Inc., Post Office Box 98521, Las Vegas, NV 89193-8521, M/S 709

L. E. Barker, Environmental Restoration Projects, Reynolds Electrical \& Engineering Co., Inc., Post Office Box 98521, Las Vegas, NV 89193-8521, M/S 417

B. P. Smith, Performance Assurance Department, Reynolds Electrical \& Engineering Co., Inc., Post Office Box 98521, Las Vegas, NV 89193-8521, M/S 440

R. H. Guyman, Reynolds Electrical \& Engineering Co., Inc., Post Office Box 98521, Las Vegas, NV 89193-8521

W. G. Jacobs, Reynolds Electrical \& Engineering Co., Inc., Post Office Box 98521, Las Vegas, NV 89193-8521, M/S 935

BECAMP Library, Reynolds Electrical \& Engineering Co., Inc., Post Office Box 98521, Las Vegas, NV 89193-8521, M/S 740 


\section{Distribution List, cont.}

S. C. Black, Environmental Information Center, Reynolds Electrical \& Engineering Co., Inc.; Post Office Box 98521, Las Vegas, NV 89193-8521, M/S 412

W. M. Glines, Environmental Information Center, Reynolds Electrical \& Engineering Co., Inc., Post Office Box 98521, Las Vegas, NV 89193-8521, M/S 412

\section{DOE/NV}

Director, Environmental Protection Division, Nevada Operations Office, U.S. Department of Energy, Post Office Box 98518, Las Vegas, NV 89193-8518, M/S 505

G. N. McNeil, Environmental Protection Division, Nevada Operations Office, U.S. Department of Energy, Post Office Box 98518, Las Vegas, NV 89193-8518, M/S 505

R. C. Furlow, Environmental Protection Division, Nevada Operations Office, U.S. Department of Energy, Post Office Box 98518, Las Vegas, NV 89193-8518, M/S 505

B. Yoerg, Environmental Protection Division, Nevada Operations Office, U.S. Department of Energy, Post Office Box 98518, Las Vegas, NV 89193-8518, M/S 505

E. F. Rucker, Assistant Manager for Operations, Nevada Operations Office, U.S. Department of Energy, Post Office Box 98518, Las Vegas, NV 89193-8518, M/S 505

Director, Nevada Test Site Operations Office, U.S. Department of Energy, Post Office Box 98518, Las Vegas, NV 89193-8518, M/S 505

Technical Information Resource Center, Nevada Operations Office, U.S. Department of Energy, Post Office Box 98518, Las Vegas, NV 89193-8518, M/S 505

\section{$\underline{\text { RSN }}$}

Manager, Environmental Services Department, Ratheon Services Nevada, Post Office Box 95487, Las Vegas, NV 89193-5487, M/S 580 (2)

D. A. Gonzalez, Raytheon Services Nevada, Post Office Box 95487, Las Vegas, NV 89193-5487, M/S 580

D. P. Schlick, Raytheon Services Nevada, Post Office Box 95487, Las Vegas, NV 89193-5487, M/S 580

\section{Miscellaneous}

Office of Scientific and Technical Information, Technical Center, U.S. Department of Energy Post Office Box 62, Oak Ridge, TN 37831 (2)

L. R. Walker, Department of Biological Sciences, University of Nevada Las Vegas, 4505 Maryland Parkway, Las Vegas, NV 89154-4004 